\title{
Impacts of climate and emission changes on nitrogen deposition in Europe: a multi-model study
}

\author{
D. Simpson ${ }^{1,2}$, C. Andersson 3 , J.H. Christensen ${ }^{4}$, M. Engardt ${ }^{3}$, C. Geels ${ }^{4}$, A. Nyiri ${ }^{1}$, M. Posch ${ }^{5}$, J. Soares ${ }^{6}$, M. Sofiev ${ }^{6}$, \\ P. Wind ${ }^{1,7}$, and J. Langner ${ }^{3}$ \\ ${ }^{1}$ EMEP MSC-W, Norwegian Meteorological Institute, Oslo, Norway \\ ${ }^{2}$ Dept. Earth \& Space Sciences, Chalmers University of Technology, Gothenburg, Sweden \\ ${ }^{3}$ Swedish Meteorological and Hydrological Institute, Norrköping, Sweden \\ ${ }^{4}$ Department of Environmental Science, Aarhus University, 4000 Roskilde, Denmark \\ ${ }^{5}$ National Institute for Public Health and the Environment (RIVM), Bilthoven, the Netherlands \\ ${ }^{6}$ Finnish Meteorological Institute, P.O. Box 503, 00101 Helsinki, Finland \\ ${ }^{7}$ University of Troms $\emptyset, 9037$ Troms $\emptyset$, Norway \\ Correspondence to: D. Simpson (david.simpson@met.no)
}

Received: 28 January 2014 - Published in Atmos. Chem. Phys. Discuss.: 13 March 2014

Revised: 16 May 2014 - Accepted: 2 June 2014 - Published: 9 July 2014

\begin{abstract}
The impact of climate and emissions changes on the deposition of reactive nitrogen $(\mathrm{Nr})$ over Europe was studied using four offline regional chemistry transport models (CTMs) driven by the same global projection of future climate over the period 2000-2050. Anthropogenic emissions for the years 2005 and 2050 were used for simulations of both present and future periods in order to isolate the impact of climate change, hemispheric boundary conditions and emissions, and to assess the robustness of the results across the different models.

The results from these four CTMs clearly show that the main driver of future $\mathrm{N}$-deposition changes is the specified emission change. Under the specified emission scenario for 2050, emissions of oxidised nitrogen were reduced substantially, whereas emissions of $\mathrm{NH}_{3}$ increase to some extent, and these changes are largely reflected in the modelled concentrations and depositions. The lack of sulfur and oxidised nitrogen in the future atmosphere results in a much larger fraction of $\mathrm{NH}_{\mathrm{x}}$ being present in the form of gaseous ammonia.

Predictions for wet and total deposition were broadly consistent, although the three fine-scale models resolve European emission areas and changes better than the hemisphericscale model. The biggest difference in the models is for predictions of individual $\mathrm{N}$ compounds. One model (EMEP) was used to explore changes in critical loads, also in conjunc-
\end{abstract}

tion with speculative climate-induced increases in $\mathrm{NH}_{3}$ emissions. These calculations suggest that the area of ecosystems that exceeds critical loads is reduced from $64 \%$ for year 2005 emissions levels to $50 \%$ for currently estimated 2050 levels. A possible climate-induced increase in $\mathrm{NH}_{3}$ emissions could worsen the situation, with areas exceeded increasing again to $57 \%$ (for a $30 \% \mathrm{NH}_{3}$ emission increase).

\section{Introduction}

As noted in Langner et al. (2012b), air pollution is still a major problem in Europe, with levels of gases and particles frequently exceeding target values. Many sensitive ecosystems are adversely affected by deposition of reactive nitrogen $(\mathrm{Nr})$ from the atmosphere to vegetation and water bodies (Erisman et al., 2013; Sutton et al., 2011). Nr comprises both oxidised and reduced compounds, generally indicated by $\mathrm{NO}_{\mathrm{y}}$ and $\mathrm{NH}_{\mathrm{x}}$ respectively. Important $\mathrm{NO}_{\mathrm{y}}$ compounds include $\mathrm{NO}$ and $\mathrm{NO}_{2}$ (together known as $\mathrm{NO}_{\mathrm{x}}$ ) as well as species such as $\mathrm{HNO}_{3}$ or particulate nitrates. The dominant $\mathrm{NH}_{\mathrm{X}}$ compounds are gaseous ammonia $\left(\mathrm{NH}_{3}\right)$ and particulate ammonium, the latter usually associated with either sulfates or nitrate. Although emissions of $\mathrm{NO}_{\mathrm{x}}$ in Europe are expected to keep decreasing in the future, emissions of $\mathrm{NH}_{3}$ may well increase in line with agricultural activities. An important new 
realisation is that increased temperatures associated with climate change may induce additional $\mathrm{NH}_{3}$ emissions through increased evaporation (Skjøth and Geels, 2013; Sutton et al., 2013); these studies suggest possible increases of $20-50 \%$ over the next century.

Changes in atmospheric circulation due to climate change can also affect future levels of air pollution and $\mathrm{Nr}$ deposition (e.g. Engardt and Langner, 2013, and references cited therein). Changes in meteorological conditions further influence local dispersion and deposition conditions to vegetation and thereby influence the effects of both long-range transported and locally emitted air pollutants on human health and ecosystems. Since the 1990s the concentration of S components in the Arctic has declined, while the pattern for N components is more complex, showing both positive and negative trends. These interannual variations reflect the significant reductions in sulfur emissions in North America and Europe as well as interannual variations in synoptic transport and precipitation (Hole et al., 2009).

The link between climate change and air pollution in Europe has been assessed in several recent studies using regional chemistry transport models (CTMs) (e.g. Langner et al., 2005, 2012a, b; Forkel and Knoche, 2007; Hedegaard et al., 2008; Andersson and Engardt, 2010; Colette et al., 2012; Engardt and Langner, 2013). The majority of these studies have focused on ozone concentrations, but, for example, Hole and Engardt (2008), Langner et al. (2009), Hedegaard et al. (2013) and Engardt and Langner (2013) presented some results for nitrogen species. Likewise, a number of studies have made projections of the future $\mathrm{N}$ deposition in Europe and the Arctic which included emission changes (e.g. Hole et al., 2009; Geels et al., 2012b; Engardt and Langner, 2013; Tuovinen et al., 2013, the latter using EMEP model results from the present exercise).

Several multi-model studies of atmospheric chemistry and long-range transport of air pollution in Europe have been carried out over the last decade (e.g. Vautard et al., 2006, 2007; van Loon et al., 2007; Cuvelier et al., 2007; Thunis et al., 2007; Colette et al., 2011; Solazzo et al., 2012; Dore et al., 2013), also at the hemispheric scale (Dentener et al., 2006; Sanderson et al., 2008). These studies have focused on establishing the robustness of model predictions in the present climate, although Lamarque et al. (2005) used global-scale models with projections up to 2100 .

Here we assess the combined uncertainty of predicting future climate, emissions and atmospheric chemistry as well as long-range transport of $\mathrm{Nr}$ over Europe, using finer-scale climate projections than used in previous studies, and with common emissions and meteorological systems. This study complements that of Engardt and Langner (2013), which used one CTM (MATCH) and examined the effects of using different meteorological drivers. Here we take a multi-model approach using four state-of-the-art offline CTMs to assess the uncertainty/robustness of model predictions of nitrogen deposition over Europe. Specifically, we evaluate the sensi- tivity of simulated $\mathrm{Nr}$ deposition over Europe to changes in climate, changes in boundary conditions, and to emissions.

This study is a follow-up to the ozone study of Langner et al. (2012b), and largely follows the same methodology except in three respects: (i) the emission inventories were updated (see Sect. 2.1), making use of recent improvements in data sets and finer-scale spatial distributions to provide more accurate model inputs; (ii) we have investigated the effects of emissions changes as well as of climate change; and (iii) $20 \mathrm{yr}$ time windows of simulation were considered instead of $10 \mathrm{yr}$. The choice of $20 \mathrm{yr}$ time windows was primarily driven by the strong interannual variability in precipitation and resulting interannual variability in wet deposition in the CTMs. Using shorter simulation periods leads to deposition changes driven by climate change that are not significant for large areas of the simulation domain. The use of $20 \mathrm{yr}$ time windows also smoothes some of the decadal variability present in the climate model output. An even longer time window could have been considered, but $20 \mathrm{yr}$ was found to be a good compromise between computational effort and level of significance.

\section{Methods}

This study uses the same basic model chain as in the ozone study of Langner et al. (2012b). Briefly, we focus on the comparison of $\mathrm{Nr}$ simulations from three Europeanscale CTMs (EMEP MSC-W, MATCH and SILAM) and one hemispheric CTM (DEHM). In order to obtain climatesensitive meteorology, meteorological data from a global climate model (GCM) were used in both a regional climate model (RCM) and an offline hemispheric chemical transport model (DEHM). The downscaled meteorology from the RCM is used together with time-varying boundary conditions from the hemispheric DEHM CTM to drive the three European-scale CTMs. The horizontal grid for these CTMs was identical to the RCA3 grid, while the vertical discretisation was left free to each model.

Three scenarios with the hemispheric model, and four scenarios with the European RCA3-driven CTMs, were needed to isolate and explore the effects of changing emissions, climate and boundary conditions, as summarised in Table 1 for the region of the EU28 plus Norway and Switzerland (hereafter called EU28 $\left.{ }^{+}\right)$. Emissions were either from the year 2005 or 2050 (which we denote "E05" and "E50"). Climate was investigated with differences in meteorology between that for 1990-2009 (which we denote the "2000s", or "M00") and 2040-2059 (the "2050s", or "M50"). Three sets of runs (denoted BC1, BC2 and BC3) with the hemispheric DEHM model provided boundary conditions to the other CTMs for either the 2000s or 2050s periods, with the difference between $\mathrm{BC} 2$ and $\mathrm{BC} 3$ reflecting changes in hemispheric emissions, particularly those of North America. 
Table 1. Model runs used in this study.

\begin{tabular}{lccccl}
\hline Label & Emis. & Meteor. & BIC label & DEHM setup & Comment \\
\hline E05-M00-BC1 & 2005 & $1990-2009$ & BC1 & E05-M00 & Base case - current conditions \\
E05-M50-BC2 & 2005 & $2040-2059$ & BC2 & E05-M50 & Climate change only \\
E05-M50-BC3 & 2005 & $2040-2059$ & BC3 & E50-M50 & Climate+boundary condition changes \\
E50-M50-BC3 & 2050 & $2040-2059$ & BC3 & E50-M50 & Future conditions \\
& & & & & \\
E50X20-M50-BC3 & 2050 & $2040-2059$ & BC3 & E50-M50 & $20 \%$ more $\mathrm{NH}_{3}$, EMEP, DEHM only \\
E50X30-M50-BC3 & 2050 & $2040-2059$ & BC3 & E50-M50 & $30 \%$ more $\mathrm{NH}_{3}$, EMEP only \\
\hline
\end{tabular}

Notes: the BIC label is shorthand for the boundary and initial conditions provided by the DEHM model using the setup for emissions and meteorology given here; see Sect. 2.

Two final scenarios are included in Table 1, E50X20-M50$\mathrm{BC} 3$ and E50X30-M50-BC3, both of which are run with just one or two models as a more speculative exercise. These scenarios are added in order to address the possible increased emissions of ammonia resulting from increased temperatures (Skjøth and Geels, 2013; Sutton et al., 2013). This exercise will be discussed in Sects. 2.1.1 and 4. Details of the emission data, scenarios and models follow.

\subsection{Emissions}

The models used in this study require emissions of sulfur and nitrogen oxides $\left(\mathrm{SO}_{\mathrm{x}}, \mathrm{NO}_{\mathrm{x}}\right), \mathrm{NH}_{3}$, non-methane volatile organic compounds (NMVOCs), and $\mathrm{CO}$, and $\mathrm{CH}_{4}$ for DEHM. The anthropogenic emissions consist of annual, gridded data sets. Ten major types of anthropogenic emissions are used, classified with the so-called "SNAP"-level emission sectors (SNAP stands for Source Nomenclature of Air Pollutants; for example, SNAP-7 is road traffic, SNAP-10 is agriculture, etc.).

In this study, all models made use of the same emission files, which contained gridded SNAP-level data on the RCA3 grid (and a global grid for DEHM). A number of emission inventories that became available in 2012 were merged for this study, aiming to provide consistency with databases used within the EU ECLAIRE project (http://www.eclaire-fp7. $\mathrm{eu} /$ ) and best-possible spatial resolution for the underlying data. The latter aspect is important as the emissions need to be interpolated to the rotated latitude-longitude grid system of the RCA model, and the finer the base grid, the more accurate such interpolation can be.

A three-step procedure was used to generate the common emissions database used by all models. Firstly, the main database, supplying national SNAP-sector emissions for all countries, consists of the so-called ECLIPSE data as produced by the International Institute for Applied System Analysis (IIASA). These data, for both 2005 and 2050, were produced for the EU ECLIPSE project (e.g. Stohl et al., 2013) and the Task Force on Hemispheric Transport of Air Pollution (Amann et al., 2013). The original (ECLIPSE v.4) databases produced in 2012 were updated in February 2013
Table 2. Emissions for $\mathrm{EU}_{28^{+}}$used in the calculations for 2005 and 2050. Data from the IIASA/ECLIPSE v. $4^{e}$ data set; see text. Unit: $\mathrm{Tg} \mathrm{yr}^{-1}\left(\mathrm{SO}_{\mathrm{x}}\right.$ as $\mathrm{SO}_{2}, \mathrm{NO}_{\mathrm{x}}$ as $\left.\mathrm{NO}_{2}\right)$.

\begin{tabular}{lcccc}
\hline Year & $\mathrm{SO}_{\mathrm{x}}$ & $\mathrm{NO}_{\mathrm{x}}$ & $\mathrm{NH}_{3}$ & NMVOC \\
\hline 2005 & 8.41 & 12.5 & 3.99 & 10.1 \\
2050 & 2.10 & 4.10 & 4.04 & 5.94 \\
Change (\%) & -75 & -67 & +1 & -41 \\
\hline
\end{tabular}

Notes: EU $28^{+}$here denotes the $28 \mathrm{EU}$ countries, plus Norway and Switzerland.

for the ECLAIRE project; we denote these data as ECLIPSE v. $4^{e}$. Secondly, for countries within the so-called MACC area (this includes all of the EU, plus some neighbours), the $7 \mathrm{~km}$ resolution MACC-2 emissions produced by TNO (Kuenen et al., 2011) were used to spatially distribute the countryspecific SNAP emissions. For other countries the IIASA $0.5^{\circ} \times 0.5^{\circ}$ spatial resolution was preserved. Finally, international shipping emissions were added from the RCP6.0 data sets (Hijioka et al., 2008). This scenario was chosen in discussion with IIASA as most appropriate for the ECLIPSE/ECLAIRE assumptions.

Emission data sets using this procedure were provided for the years 2005 and a 2050 "current legislation" (CLE) scenario. The EU totals are presented in Table 2. Figure 1 illustrates the 2005 emissions for $\mathrm{NO}_{\mathrm{x}}$ and $\mathrm{NH}_{3}$ in the RCA3 domain used by the three European-scale CTMs, and Fig. 2 shows the changes in emissions between 2005 and 2050. The changes for $\mathrm{NO}_{\mathrm{x}}$ are dramatic across almost the whole EU area. In Germany, for example, emissions decrease by nearly $70 \%$. Dramatic emissions increases are also seen in some areas, especially in northern Africa and Turkey. For $\mathrm{NH}_{3}$, the emission changes are more complex, with increases and decreases even within the EU area, and dramatic increases in some Russian areas especially.

It should be noted that these ECLIPSE v.4 2050 emissions are not the same as the so-called RCP emissions which were developed recently for the IPCC process (van Vuuren et al., 2011) because of very different assumptions concerning energy pathways and legislation. The ECLIPSE 


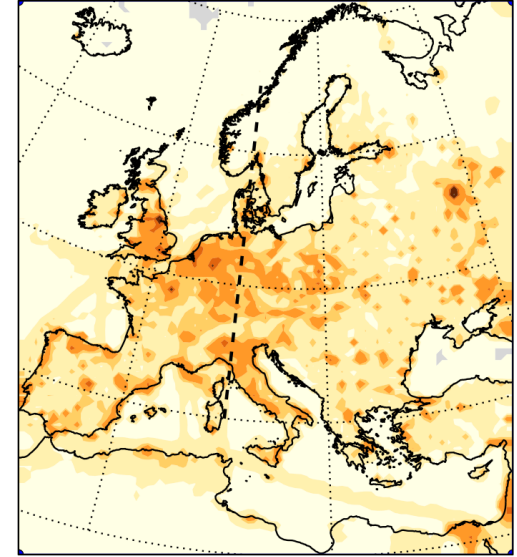

(a) $\mathrm{NOx}$

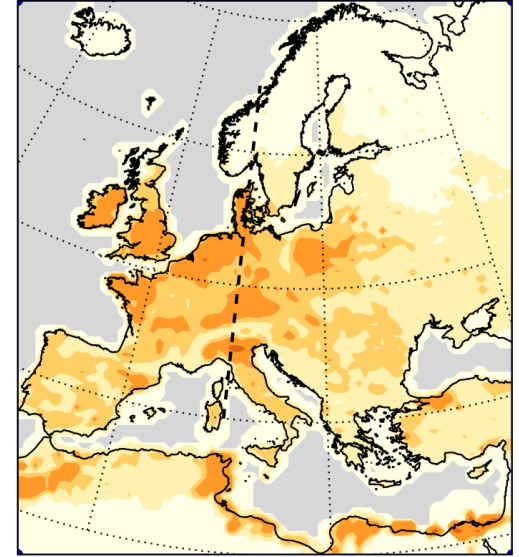

(b) $\mathrm{NH}_{3}$

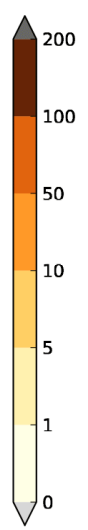

Figure 1. Emissions of $\mathrm{NO}_{\mathrm{x}}$ and $\mathrm{NH}_{3}$ for the 2005 base year. Unit: $\mathrm{kg}(\mathrm{N})$ ha ${ }^{-1}$. Also indicated is the transect line through $10^{\circ} \mathrm{E}$ used in Figs. 4, 8 and 9 .

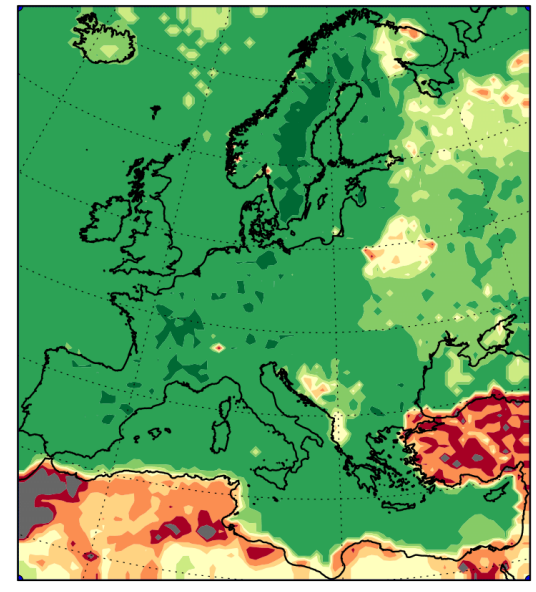

(a) $\mathrm{NOx}$

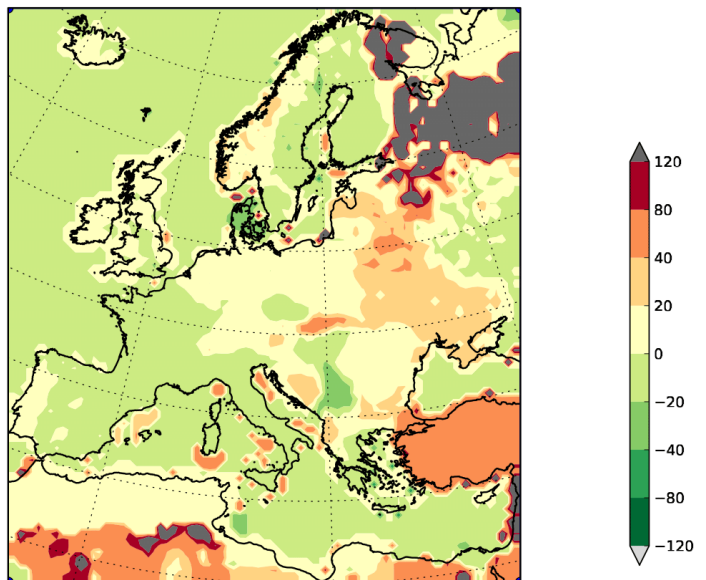

(b) $\mathrm{NH}_{3}$

Figure 2. Emissions changes (\%), 2005 to 2050, of $\mathrm{NO}_{\mathrm{x}}$ and $\mathrm{NH}_{3}$.

projections assume business-as-usual economic development and implementation of all currently agreed emission control legislation (cf. Amann et al., 2012, 2013). They also make much more use of detailed national data, and are believed more appropriate than RCP for air quality modelling. However, the large $(67 \%) \mathrm{NH}_{\mathrm{x}}$ emission reductions seen in Table 2 are broadly consistent with RCP changes for EU27 presented in Winiwarter et al. (2011). Emissions of $\mathrm{NH}_{\mathrm{x}}$ are predicted to remain almost constant in Table 2, whereas RCP estimates suggest either a significant increase (ca. 25\% for RCP8.5) or decrease (ca. $25 \%$ for RCP2.6 and RCP4.5). There are of course considerable uncertainties in all these projections, arising from assumptions concerning technical measures, growth and policies (Amann et al., 2013).

A number of other emissions sources are typically used in the CTMs. These include so-called natural $\mathrm{NO}_{\mathrm{x}}$ emissions from soils; NMVOC from vegetation; and emissions from forest fires, aircraft and lightning. The CTMs have different approaches to these emissions sources, and harmonising these was beyond the scope of our study. Instead, in order to simplify the interpretation of the CTM results, we have adopted the simple policy of setting emissions from soils, forest fires, aircraft and lightning to zero, so that all $\mathrm{NO}_{\mathrm{x}}$ emissions in the models stem from the common emission data set discussed above. In contrast to these minor emission sources, emissions of NMVOC from vegetation are too great to ignore (e.g. Simpson et al., 1999), and as in Langner et al. (2012b), each model simply calculates its own emissions at each model time step (differences in isoprene emissions were indeed substantial, ranging from ca. 1600 to $8000 \mathrm{Gg} \mathrm{yr}^{-1}$ as annual average for the models used here; see Langner et al. $2012 \mathrm{~b}$ for details and more discussion). Similarly, volcanic emissions are a significant fraction of European $\mathrm{S}$ emissions. 
The official EMEP estimate of volcanic emissions was used for all models.

\subsubsection{A possible future - increased $\mathrm{NH}_{3}$ emissions?}

Two recent papers have drawn attention to the possibility of quite significant increases in $\mathrm{NH}_{3}$ emissions in the future as a result of increasing evaporation from sources such as animal manure. These emissions are a function of both water availability and temperature with, in principle, a doubling of the emission for each $5^{\circ} \mathrm{C}$ increase. Sutton et al. (2013), using empirical models and measurements, estimated a potential $42 \%$ increase in the global $\mathrm{NH}_{3}$ emissions following a $5{ }^{\circ} \mathrm{C}$ increase towards 2100. Skjøth and Geels (2013) used a dynamic $\mathrm{NH}_{3}$ emission model (Skjøth et al., 2011) to study the temporal and geographical variations in ammonia emissions across the northern part of Europe. By using biascorrected ensemble mean surface temperatures from the ENSEMBLES project (van der Linden and Mitchell, 2009), the potential future changes in the emission from a typical Danish pig stable were tested in different locations and hence climates. Towards the 2050s a general increase of $15-30 \%$ (relative to 2007) was found in the emissions in central to northern Europe, increasing to ca. $20-40 \%$ by the end of the century. It is reasonable to postulate that such increased emissions have the potential to partially offset many of the beneficial effects of European $\mathrm{NO}_{\mathrm{y}}$ emissions reductions. The fact that more $\mathrm{NH}_{\mathrm{x}}$ will be in the form of $\mathrm{NH}_{3}$ rather than $\mathrm{NH}_{4}^{+}$ (see Sect. 3.4) also suggests the possibility of quite large increases in near-source deposition if such emissions increases occur. The projected increase will of course depend heavily on the projected temperature change and hence on the applied climate model, as well as assumptions concerning $\mathrm{NH}_{3}$ emission factors. However, based on the above studies we have chosen to explore the potential impact of a 20 and $30 \%$ increase in $\mathrm{NH}_{3}$ emissions in our future period 2040-2059 in two scenarios denoted E50X20-M50-BC3 and E50X30M50-BC3 (Table 1). Given the speculative nature of this exercise, we have used just the DEHM (for 20\%) and EMEP (for 20 and $30 \%$ ) models, with a focus on the impact of these scenarios on the critical loads calculations we will present in Sect. 4.

\subsection{Climate meteorology}

Results of the global-scale ECHAM5 general circulation model (GCM) (Roeckner et al., 2006), driven by emissions from the SRES A1B scenario (Nakićenović, 2000), were downscaled over Europe with the Rossby Centre Regional Climate model (RCM) version 3 (RCA3) (Samuelsson et al., 2011; Kjellstrom et al., 2011). Details and discussion of both current and future climate simulated with RCA3 are given in Samuelsson et al. (2011) and Kjellstrom et al. (2011). Here we used the so-called ECHAM5-r3 downscaling from the SRES A1B emission scenario (see Kjellstrom et al., 2011, for details). The ECHAM5 version used is defined in a spectral grid with truncation T63, which at mid-latitudes corresponds to a horizontal resolution of ca. $140 \mathrm{~km} \times 210 \mathrm{~km}$. The temporal resolution of the climate data was 6 hourly.

As in Langner et al. (2012b), the horizontal resolution of RCA3 was $0.44^{\circ} \times 0.44^{\circ}$ (ca. $50 \mathrm{~km} \times 50 \mathrm{~km}$ ) on a rotated latitude-longitude grid, and data were provided with 6-hourly resolution. The climate as downscaled by RCA3 reflects broad features of the climate simulated by the parent GCM. The average temperature change in the period 20002040 predicted by RCA3 for the European model domain in the downscaled ECHAM5-r3 is $1.27^{\circ} \mathrm{C}$. Until the period 2040-2070, this climate projection has a temperature change close to the average of an ensemble of 16 different projections downscaled from different GCM runs by RCA3 over Europe (Kjellstrom et al., 2011).

Figures S1 and S2 (see Supplement) illustrate the changes in temperature and precipitation between our $20 \mathrm{yr}$ time slices, from both the ECHAM-5 and RCA3 data. Although the general patterns of temperature are similar, the RCA3 temperature has clearly a higher spatial resolution than the ECHAM5 data, which is particularly obvious over the Alpine area. Temperature increases up to the 2050s are somewhat greater in the ECHAM5 system.

For precipitation the increased resolution of RCA3 is also very evident. ECHAM5 has substantially more rainfall over most of Europe, but less so in some areas, e.g. western Norway or the Alps. However both models show rather similar large-scale changes in precipitation to the 2050s, with rather large increases (ca. 10\%) in north-eastern Europe, and decreases of around $10 \%$ around the Mediterranean.

\subsection{Chemical boundary conditions}

As in Langner et al. (2012b), chemical boundary conditions at lateral and top boundaries of the regional models were provided by the hemispheric DEHM model, which was also driven by the global ECHAM5-r3 meteorology. The boundary values taken from DEHM were updated every $6 \mathrm{~h}$ and interpolated from the DEHM resolution to the respective geometry of each regional CTM. To ensure consistency, the offline DEHM model was operated with global emissions for 2005 and 2050 from the same system as used for the European-scale CTMs.

\subsection{The chemical transport models}

The models used in this study have been introduced in our preceding multi-model study, Langner et al. (2012b). Here we just briefly review the models with focus on their handling of $\mathrm{Nr}$ compounds. 


\subsubsection{DEHM}

The Danish Eulerian Hemispheric Model (DEHM) is a threedimensional, Eulerian CTM (Christensen, 1997; Frohn et al., 2002; Brandt et al., 2012; Geels et al., 2012a) developed at the Danish National Environmental Research Institute (now Aarhus University). The model domain covers most of the Northern Hemisphere, discretised on a polar stereographic projection, and includes a two-way nesting procedure with several nests with higher resolution over Europe, northern Europe and Denmark (Frohn et al., 2002). In the vertical the model has 20 unevenly distributed layers defined in a terrain-following sigma-level coordinate system with a top at $100 \mathrm{hPa}$.

The chemical scheme comprises 58 photo-chemical compounds, 9 classes of particulate matter and 122 chemical reactions. The original scheme by Strand and Hov (1994) has been extended to include species relevant for the ammonium group chemistry. This includes ammonia $\left(\mathrm{NH}_{3}\right)$, ammonium nitrate $\left(\mathrm{NH}_{4} \mathrm{NO}_{3}\right)$, ammonium bisulfate $\left(\mathrm{NH}_{4} \mathrm{HSO}_{4}\right)$, ammonium sulfate $\left(\left(\mathrm{NH}_{4}\right)_{2} \mathrm{SO}_{4}\right)$ and inorganic nitrates. Gaseous and aerosol dry-deposition velocities are calculated based on the resistance method and are parameterised similar to the EMEP model (Simpson et al., 2003a; Emberson et al., 2000a) except for the dry deposition of species on water surfaces where the deposition depends on the solubility of the chemical species and the wind speed (Asman et al., 1994; Hertel et al., 1995). Wet deposition includes in-cloud and below-cloud scavenging and is calculated as the product of scavenging coefficients and the concentration in air.

Natural emissions of isoprene are calculated dynamically in the model according to the IGAC-GEIA biogenic emission model (International Global Atmospheric Chemistry Global Emission Inventory Activity) (Guenther et al., 1995).

Background $\mathrm{CH}_{4}$ concentrations were assumed to be $1760 \mathrm{ppb}$ in all scenarios. As well as simplifying the interpretation of changes, this is consistent with John et al. (2012), who suggest that the atmospheric $\mathrm{CH}_{4}$ is not projected to change much under all but the most extreme RCP scenarios. DEHM is regularly validated against observations of, for example, acidifying and eutrophying compounds (Brandt et al., 2012; Geels et al., 2012b, 2005).

\subsubsection{EMEP MSC-W}

The gaseous nitrogen species in the EMEP model that are subject to dry deposition are $\mathrm{NO}_{2}, \mathrm{HNO}_{2}, \mathrm{HNO}_{3}, \mathrm{PAN}$, MPAN and $\mathrm{NH}_{3}$ (see Simpson et al., 2012, for explanation of PAN species). The surface resistance scheme is quite complex, featuring vegetation-specific corrections for phenology (time of year), temperature, humidity and soil water. The stomatal-uptake part of the scheme has been developed and tested for ozone in a series of papers (Emberson et al., 2001, 2000a, b, 2007; Klingberg et al., 2008; Simpson et al., 2001, 2003b; Tuovinen et al., 2001, 2004).
The bulk surface conductance in the EMEP model is calculated specifically for $\mathrm{O}_{3}, \mathrm{SO}_{2}$ and $\mathrm{NH}_{3}$. Values for other gases (except $\mathrm{HNO}_{3}$ ) are obtained by interpolation of the $\mathrm{O}_{3}$ and $\mathrm{SO}_{2}$ values. For ammonia and sulfur dioxide, deposition rates also depend on humidity levels, temperature and an acidity ratio (defined as the molar ratio of $\left[\mathrm{SO}_{2}\right] /\left[\mathrm{NH}_{3}\right]$ ). These acidity ratios are a first attempt to account for the observed changes in resistance in areas with different pollution climates (Erisman et al., 2001; Fowler and Erisman, 2003; Fowler et al., 2009). For $\mathrm{NO}_{2}$ the deposition velocity is reduced as air concentrations approach $4 \mathrm{ppb}$ (a pseudocompensation point). Further, $\mathrm{NH}_{3}$ deposition is switched off over growing crops, a simple way to account for the bidirectional fluxes expected over such areas. For further details, see Simpson et al. (2012).

The particulate nitrogen species in the EMEP model that are subject to dry deposition are fine and coarse nitrate, as well as ammonium. Aerosol deposition in the EMEP model has been considerably simplified in recent years. The new formulation (Simpson et al., 2012) uses a simple $u_{*}$ dependence as in many studies (Wesely et al., 1985; Lamaud et al., 1994; Gallagher et al., 1997; Nemitz et al., 2004), but modified by an enhancement factor for nitrogen compounds in unstable conditions; see Simpson et al. (2012) for details. The settling velocities of coarse particles are calculated as in Binkowski and Shankar (1995). Comparison of EMEP model results with observations of acidifying compounds can be found in annual EMEP reports (www.emep.int), in several papers (Aas et al., 2012; Fagerli and Aas, 2008; Simpson et al., 2006a, b), and as part of a multi-model comparison in the UK (Dore et al., 2013).

\subsubsection{MATCH}

In this study, oxidised nitrogen in MATCH consists of the gases $\mathrm{NO}, \mathrm{NO}_{2}, \mathrm{HNO}_{3}$, peroxyacetyl nitrate (PAN), $\mathrm{N}_{2} \mathrm{O}_{5}$, particulate nitrate, $\mathrm{NO}_{3}$ radicals and the isoprene$\mathrm{NO}_{3}$ adduct. Reduced nitrogen is made up of $\mathrm{NH}_{3}$ and particulate ammonium.

Wet deposition is, for most species, calculated as a heightvarying scavenging coefficient times surface precipitation intensity. For ozone, hydrogen peroxide and sulfur dioxide, in-cloud scavenging is calculated by assuming Henry's law equilibrium; sub-cloud scavenging is neglected for these species. To calculate dry deposition, MATCH uses a resistance approach based on surface type and atmospheric stability. Species that enter the stomata of plants (i.e. most gases) display a diurnal variation in surface resistance based on a specified, monthly varying, surface-type-specific, nonstomatal deposition velocity plus a diurnally varying term that is zero during night and reaches its specified maximum during local noon. In this study, we discriminate between four different surface types: water, low vegetation, high vegetation (i.e. forest) and barren land (including urban areas). For non-water surfaces the dry-deposition velocity is 
decreased by low temperatures or snow cover. For ozone, the surface resistance is affected by photosynthetic active radiation, soil moisture and temperature (see Andersson and Engardt, 2010). Particulate matter and some gases have monthly varying dry-deposition velocities that only vary according to land surface. Numerical values of most dry-deposition velocities and scavenging coefficients are given in Andersson et al. (2007).

Details of the numerics, boundary layer parameterisation and deposition parameterisation are given in Robertson et al. (1999) and Engardt (2000). The chemistry, based upon Simpson et al. (1993), has strong links between $\mathrm{Nr}$ compounds and sulfur compounds, as well as ozone. The implementation is described in Langner et al. (1998), although several of the rate constants have been updated. The ability of MATCH to reproduce the concentration and deposition of acidifying and eutrophying species when forced by data from RCA3 is discussed in, for example, Engardt and Langner (2013) and Langner et al. (2009). In Andersson et al. (2007) MATCH is evaluated when forced with meteorology from ERA-40.

\subsubsection{SILAM}

The SILAM model (System for Integrated modeLling of Atmospheric coMposition) is documented in Sofiev et al. (2008), Huijnen et al. (2010) and Kukkonen et al. (2012). The system includes a meteorological pre-processor for evaluation of basic features of the boundary layer and the free troposphere using the meteorological fields provided by numerical weather prediction (NWP) data (Sofiev et al., 2010). The physical-chemical modules of SILAM include several tropospheric chemistry schemes, description of primary anthropogenic and natural aerosols, and radioactive processes. For the current study the transformation scheme utilised is the updated version of the DMAT chemical scheme (Sofiev, 2000), which incorporates the main formation pathways of secondary inorganic aerosols: the scheme covers 21 transported and 5 short-lived substances, which are interrelated via ca. 60 chemical reactions. Nitrogen components include $\mathrm{NO}, \mathrm{NO}_{2}, \mathrm{~N}_{2} \mathrm{O}_{5}, \mathrm{NO}_{3}$ radical, $\mathrm{HONO}, \mathrm{HNO}_{3}, \mathrm{PAN}, \mathrm{NH}_{3}$, $\mathrm{NH}_{4} \mathrm{NO}_{3}$ (in $\mathrm{PM}_{2.5}$ ), $\left(\mathrm{NH}_{4}\right)_{1.5} \mathrm{SO}_{4}$ (in $\mathrm{PM}_{2.5}$ and $\mathrm{PM}_{10}$ ) and coarse nitrates formed on the surface of sea salt particles, Here (NH4) ${ }_{1.5} \mathrm{SO}_{4}$ denotes an equal-fraction mixture of ammonium mono- and bisulfate. Formation and break-up of ammonium nitrate follows the temperature-dependent equilibrium parameterisation suggested by Finlayson-Pitts and Pitts (2000).

The removal processes are described via dry and wet deposition. Gaseous deposition discriminates land-sea, wet-dry and frozen-unfrozen surfaces.

Depending on particle size, mechanisms of dry deposition vary from primarily turbulent diffusion-driven removal of fine aerosols to primarily gravitational settling of coarse particles (Kouznetsov and Sofiev, 2012). Wet deposition distinguishes between sub- and in-cloud scavenging by both rain and snow (Sofiev et al., 2006; Horn et al., 1987; Smith and Clark, 1989; Jylhä, 1991). Meteorological information and necessary geophysical and land cover maps are taken from the meteorological fields. The results shown in this study are based on a vertical profile represented by nine non-regularly spaced levels reaching up to the tropopause; the lowest layer is $25 \mathrm{~m}$ thick.

\subsection{Previous comparisons with trends}

Most model-measurement comparisons address the issue of how well model results match observations in current conditions. It is much harder to show that the models can capture changes in pollution with time accurately, although it can be noted that if the models work well across all of Europe, this in itself suggests they do capture the effects of changing pollution conditions in differing meteorological conditions. However, some trend studies are available, which we briefly summarise here.

For EMEP, such studies include Jonson et al. (2006) for ozone and $\mathrm{NO}_{2}$, Fagerli and Aas (2008) for $\mathrm{Nr}$ compounds in air and precipitation, and Colette et al. (2011) for $\mathrm{NO}_{2}$, $\mathrm{O}_{3}$ and $\mathrm{PM}_{10}$. Schulz et al. (2013) presented comparisons for 1990 and 2000-2011 for S compounds as well as Nr. For DEHM, previous analysis of multi-year model runs shows that the model in general reproduces the observed trends in concentrations and depositions of $\mathrm{N}$ and $\mathrm{S}$ components caused by emission changes (Geels et al., 2005, 2012b). For MATCH, Hansen et al. (2013) compared a MATCH simulation over 1980-2011, forced by EMEP emissions and ERAInterim meteorology, to observed trends in annual mean wet deposition of $\mathrm{NH}_{\mathrm{y}}$ and $\mathrm{NH}_{\mathrm{x}}$ over different regions of Sweden.

Summarising these studies, it is generally found that the models capture the broad features of trends for the $\mathrm{S}$ and $\mathrm{Nr}$ compounds over large areas, although capturing results for specific sites is more difficult. It should be noted, however, that comparisons of observed and modelled trends rely on consistency in the measurement network (sites, techniques and quality), as well as on accurate estimates of emission trends. Problems associated with these factors have been discussed in, for example, Fagerli and Aas (2008) and Colette et al. (2011).

\section{Results}

In this section we first compare the base-case model simulations against observations in order to establish reasonable model performance of the CTMs as driven by their GCM/RCM climate data, and then compare model predictions across Europe for the base-case and scenario runs. It should be noted that the CTMs have different methods of producing near-ground concentrations for comparison to measurements. DEHM and SILAM use the concentration of each 
Table 3. Evaluation of modelled air concentrations of sulfur and nitrogen gaseous and aerosol species using observations from the EMEP measurement network (http://www.emep.int) for the years 2000-2010. Unit: $\mu \mathrm{g}(\mathrm{S} / \mathrm{N}) \mathrm{m}^{-3}$.

\begin{tabular}{|c|c|c|c|c|c|c|c|c|}
\hline & $\mathrm{SO}_{2}$ & $\mathrm{NO}_{2}$ & $\mathrm{NH}_{3}$ & $\mathrm{HNO}_{3}$ & $\mathrm{SO}_{4}^{2-}$-tot & $\mathrm{SO}_{4}^{2-}-\mathrm{nss}$ & $\mathrm{NH}_{3}+\mathrm{NH}_{4}^{+}$ & $\mathrm{HNO}_{3}+\mathrm{NO}_{3}$ \\
\hline OBS & 0.76 & 2.1 & 1.2 & 0.14 & 0.66 & 0.44 & 1.3 & 0.51 \\
\hline DEHM & 0.83 & 2.0 & 0.9 & 0.23 & 0.91 & 0.59 & 2.2 & 1.1 \\
\hline EMEP & 0.68 & 1.9 & 0.7 & 0.11 & 0.58 & 0.39 & 1.1 & 0.53 \\
\hline MATCH & 0.68 & 1.8 & 0.5 & 0.09 & 0.79 & 0.54 & 1.0 & 0.34 \\
\hline SILAM & 0.58 & 2.6 & 0.8 & 0.12 & 0.29 & 0.19 & 1.6 & 1.00 \\
\hline bias-DEHM (\%) & 9 & -6 & -26 & 67 & 37 & 33 & 62 & 111 \\
\hline bias-EMEP (\%) & -11 & -9 & -46 & -16 & -12 & -12 & -14 & 4 \\
\hline bias-MATCH (\%) & -10 & -14 & -62 & -30 & 18 & 21 & -24 & -32 \\
\hline bias-SILAM (\%) & -24 & 25 & -34 & -14 & -55 & -57 & 20 & 94 \\
\hline R-DEHM & 0.67 & 0.74 & 0.85 & 0.34 & 0.69 & 0.97 & 0.74 & 0.80 \\
\hline R-EMEP & 0.62 & 0.84 & 0.90 & 0.48 & 0.78 & 0.96 & 0.79 & 0.82 \\
\hline R-MATCH & 0.55 & 0.84 & 0.88 & 0.46 & 0.71 & 0.84 & 0.75 & 0.75 \\
\hline R-SILAM & 0.50 & 0.81 & 0.91 & 0.51 & 0.76 & 0.95 & 0.76 & 0.81 \\
\hline RMSE-DEHM & 0.58 & 1.0 & 1.1 & 0.20 & 0.42 & 0.20 & 1.2 & 0.68 \\
\hline RMSE-EMEP & 0.63 & 0.83 & 1.2 & 0.15 & 0.22 & 0.09 & 0.55 & 0.17 \\
\hline RMSE-MATCH & 0.67 & 0.92 & 1.5 & 0.15 & 0.35 & 0.25 & 0.63 & 0.26 \\
\hline RMSE-SILAM & 0.76 & 1.1 & 1.1 & 0.15 & 0.43 & 0.30 & 0.7 & 0.59 \\
\hline Number of stations & 85 & 85 & 18 & 16 & 65 & 16 & 49 & 49 \\
\hline
\end{tabular}

Notes: $\mathrm{SO}_{4}^{2-}$-tot and $\mathrm{SO}_{4}^{2-}$-nss mean total and sea-salt-corrected sulfate respectively.

model's lowest layer, this being $60 \mathrm{~m}$ and $25 \mathrm{~m}$ respectively. For the EMEP and MATCH models, $3 \mathrm{~m}$ concentrations are estimated from the model's lowest layer (ca. $45 \mathrm{~m}$ grid centre for EMEP, $30 \mathrm{~m}$ for MATCH), assuming similarity theory and deposition-induced vertical gradients (Simpson et al., 2012; Robertson et al., 1999).

\subsection{Comparison with observations}

Observed concentrations of nitrogen and sulfur compounds in air and precipitation were extracted from the EMEP database (http://www.emep.int; Tørseth et al., 2012) for the years 2000-2010. Observed means were constructed for the period, with the criteria of $80 \%$ capture per year over at least $5 \mathrm{yr}$ within this period. For the four CTMs, modelled 20 yr means (1990-2009 climate, 2005 emissions) were constructed for the measurement sites reaching this criterion. The resulting paired data were evaluated for statistical performance using relative bias (\%bias), Pearson correlation coefficient $(R)$ and root-mean-square error (RMSE). The evaluation includes air concentrations of gaseous and aerosol sulfur and nitrogen species (Table 3), and deposition and concentration in precipitation of oxidised sulfur as well as oxidised and reduced nitrogen (Table 4). Evaluation of precipitation, from ECHAM5 (for DEHM) and from RCA3 (for the three European-scale CTMs), is also included in the evaluation (Table 4).
It is important to note that we cannot expect CTM models driven by GCM or RCM meteorology to perform as well as they would with data from NWP models; the latter are the result of assimilating observed data into dedicated meteorological models. The ECMWF IFS model, for example, continuously assimilates near-surface, airborne and satellite observations to ensure good performance. This NWP model has a spatial resolution of about $16 \mathrm{~km}$, and in standard usage the EMEP model updates IFS data every $3 \mathrm{~h}$. In contrast, the RCA3 data have a spatial resolution of about $50 \mathrm{~km}$, are updated every $6 \mathrm{~h}$, and have no assimilation of observations. The comparison results presented in Tables 3-4 are thus not designed to reflect optimum model performance but rather to show that, despite the limitations of RCM meteorology, the CTM models still do a reasonable job of reproducing concentration and deposition levels on a statistical basis.

From Table 3 it is clear that most models do a fair job of capturing $\mathrm{SO}_{2}$ and $\mathrm{NO}_{2}$ concentrations, but results are mixed for the other compounds. The reasons for better performance of some compounds compared to others are complex, and not always understood. However, in general we expect better performance for "simple" precursors from mainly ground-level sources (e.g. $\left.\mathrm{NO}_{2}\right)$ than from high-level point sources $\left(\mathrm{SO}_{2}\right)$, or for compounds with complex chemical pathways and strong deposition-induced gradients, notably $\mathrm{HNO}_{3} . \mathrm{HNO}_{3}$ measurements are also affected by partitioning issues with 
Table 4. Evaluation of modelled wet deposition, concentration in precipitation $\left(C_{\mathrm{p}}\right)$ and precipitation using observations from the EMEP measurement network for the years 2000-2010.

\begin{tabular}{|c|c|c|c|c|c|c|c|}
\hline & \multicolumn{3}{|c|}{$\begin{array}{c}\text { Deposition } \\
\mathrm{kg}(\mathrm{N} / \mathrm{S}) \mathrm{ha}^{-1}\end{array}$} & \multicolumn{3}{|c|}{$\begin{array}{c}C_{\mathrm{p}} \\
\mathrm{mg}(\mathrm{S} / \mathrm{N}) \mathrm{L}^{-1}\end{array}$} & \multirow[t]{2}{*}{$\begin{array}{l}\text { Precip. } \\
(\mathrm{mm})\end{array}$} \\
\hline & $\mathrm{SO}_{\mathrm{x}}$ & $\mathrm{NO}_{\mathrm{y}}$ & $\mathrm{NH}_{\mathrm{x}}$ & $\mathrm{SO}_{\mathrm{x}}$ & $\mathrm{NO}_{\mathrm{y}}$ & $\mathrm{NH}_{\mathrm{x}}$ & \\
\hline OBS & 3.10 & 2.82 & 3.34 & 0.39 & 0.34 & 0.40 & 878 \\
\hline DEHM & 3.25 & 3.00 & 3.04 & 0.45 & 0.45 & 0.41 & 770 \\
\hline EMEP & 4.18 & 2.90 & 3.54 & 0.40 & 0.40 & 0.33 & 1119 \\
\hline MATCH & 5.64 & 3.52 & 4.07 & 0.53 & 0.34 & 0.37 & 1119 \\
\hline SILAM & 2.39 & 4.85 & 3.92 & 0.22 & 0.22 & 0.35 & 1119 \\
\hline bias-DEHM (\%) & 4 & 6 & -8 & 15 & 32 & 2 & -12 \\
\hline bias-EMEP (\%) & 35 & 2 & 6 & 2 & 15 & -16 & 27 \\
\hline bias-MATCH (\%) & 82 & 24 & 21 & 33 & -1 & -5 & 27 \\
\hline bias-SILAM (\%) & -22 & 72 & 17 & -43 & -35 & -10 & 27 \\
\hline R-DEHM & 0.65 & 0.53 & 0.51 & 0.78 & 0.59 & 0.67 & 0.68 \\
\hline R-EMEP & 0.67 & 0.52 & 0.47 & 0.80 & 0.60 & 0.69 & 0.54 \\
\hline R-MATCH & 0.60 & 0.43 & 0.40 & 0.78 & 0.70 & 0.64 & 0.54 \\
\hline R-SILAM & 0.62 & 0.44 & 0.46 & 0.71 & 0.48 & 0.66 & 0.54 \\
\hline RMSE-DEHM & 1.29 & 1.52 & 1.87 & 0.16 & 0.23 & 0.17 & 323 \\
\hline RMSE-EMEP & 2.25 & 1.52 & 2.14 & 0.13 & 0.19 & 0.15 & 516 \\
\hline RMSE-MATCH & 4.06 & 1.93 & 2.63 & 0.23 & 0.12 & 0.16 & 516 \\
\hline RMSE-SILAM & 1.90 & 3.41 & 2.67 & 0.22 & 0.21 & 0.16 & 516 \\
\hline Number stations & 84 & 88 & 87 & 84 & 88 & 87 & 88 \\
\hline
\end{tabular}

Notes: for any one site, deposition is the product of $C_{\mathrm{p}} \times$ Precip, but here we present the averages across sites of each value.

ammonium nitrate and $\mathrm{NH}_{3}$ reactions. The underprediction of $\mathrm{NH}_{3}$ is, however, expected for all models as the lowest model layers (between 25 and $90 \mathrm{~m}$ thick) will not resolve vertical gradients caused by $\mathrm{NH}_{3}$ emissions, and since measurements are often affected by nearby agricultural sources; however EMEP and MATCH show the largest negative bias. The largest discrepancies in the concentrations are seen for some aerosol (or sum of gas + aerosol) components; for example, both SILAM and DEHM overestimate total nitrate by a factor of 2 . For wet deposition (Table 4), results are also mixed, but most results are within $30 \%$. Regarding wet deposition, we can note that the EMEP network is a mixture of bulk and wet-only collectors, with each country choosing the most appropriate method for its conditions (see http://ebas.nilu.no). For daily sampling, there is not thought to be a large difference in the results in many areas, but with bulk collectors, some dry-deposited material will be incorrectly assessed as wet deposition. The quality of measurement analysis also differs; results for sulfate tend to be somewhat better than nitrate, and worse for ammonium measurements (EMEP/CCC, 2014). Given these uncertainties (and the use of climate-model-based meteorology), the level of discrepancies seen in Table 4 can be regarded as satisfactory.
The results for DEHM in this setup were investigated in more detail since previous model evaluations, which usually use meteorological data from the MM5 model, show significantly better agreement with measured concentrations (Brandt et al., 2012; Geels et al., 2005). A thorough evaluation of DEHM driven by climate data from an earlier version of the ECHAM model (ECHAM4) also showed a reasonable agreement with EMEP observations (Hedegaard et al., 2008). The main reason for the poorer performance in this study seems to be very low values for the mixing height. In DEHM the mixing height is, in the current setup, described by a simple energy balance expression using information on, for example, the sensible heat flux and the friction velocity from the ECHAM5 model (Christensen, 1997). A comparison between DEHM and the EMEP model shows that the mixing height in DEHM is only $20-60 \%$ of the height in EMEP over the Mediterranean and most of the western part of Europe (see Fig. S3, Supplement). When using a setup with the MM5 model, we also get a significant higher mixing height in DEHM. 
Table 5. Base-case depositions of $\mathrm{Nr}$ components $\left(\mathrm{kg}(\mathrm{N}) \mathrm{ha}^{-1}\right)$ for the four CTMs, along with the 3CTM-ensemble mean and spread. Values are average depositions over the EU28 ${ }^{+}$domain.

\begin{tabular}{lcccccc}
\hline & DEHM & EMEP & MATCH & SILAM & $\begin{array}{c}\text { 3CTM-ensemble } \\
\text { mean }\end{array}$ & $\begin{array}{c}\text { 3CTM-ensemble } \\
\text { spread (\%) }\end{array}$ \\
\hline TDEP-Nr & 11.9 & 8.5 & 9.7 & 9.3 & 9.2 & 13 \\
TDEP-NO $_{\mathrm{y}}$ & 4.9 & 3.7 & 4.6 & 5.1 & 4.5 & 32 \\
TDEP-NH $_{\mathrm{x}}$ & 7.0 & 4.8 & 5.1 & 4.2 & 4.7 & 21 \\
WDEP-Nr $_{\text {WDEP-NO }}$ & 5.8 & 5.5 & 6.4 & 6.5 & 6.1 & 16 \\
WDEP-NH $_{\mathrm{x}}$ & 2.5 & 2.5 & 3.0 & 3.6 & 3.0 & 39 \\
DDEP-Nr $_{\text {DDEP-NO }}$ & 6.1 & 3.0 & 3.4 & 2.8 & 3.1 & 18 \\
DDEP-NH $_{\mathrm{x}}$ & 3.4 & 1.3 & 3.3 & 2.8 & 3.1 & 24 \\
\hline
\end{tabular}

Notes: the 3CTM ensemble consists of the three European-scale CTMs driven by RCA3. Spread is defined as ( $\max -\min ) / \mathrm{mean}$ of these three models. TDEP, DDEP and WDEP refer to total, dry and wet deposition respectively.

\subsection{Deposition maps, base case}

Figure 3 presents the results of the four models for total $\mathrm{Nr}$ deposition. Patterns of $\mathrm{Nr}$ deposition are seen to be generally similar across the four models, with high depositions over the major emission areas in northern Italy and the Benelux area. The DEHM model shows smoother gradients, a result of being driven by the larger scale (and lower resolution) ECHAM meteorological driver. These results are also summarised in Table 5. This table also includes the "3CTM-ensemble" mean and spread, with this small ensemble consisting of the three fine-scale models EMEP, MATCH and SILAM. (DEHM was excluded from the ensemble since its larger scale and lower spatial resolution make its results somewhat different to the RCA3-driven CTMs.) Table 5 shows similar values for the total deposition of $\mathrm{Nr}$ from the different models, with a range between 8.5 and $11.9 \mathrm{~kg}(\mathrm{~N}) \mathrm{ha}^{-1}$. The contributions from $\mathrm{NO}_{\mathrm{y}}$ and $\mathrm{NH}_{\mathrm{x}}$ are almost equal as an ensemble mean, although the models differ somewhat in their ranking of these components. The largest differences between the 3CTM-ensemble models and DEHM are seen for the drydeposition components, with factor of 2 differences. This is likely a result of the lower mixing heights in DEHM discussed in Sect. 3.1 (cf. Supplement, Fig. S3). SILAM shows the highest levels of $\mathrm{NO}_{\mathrm{y}}$ deposition (especially wet) among the four CTMs but the lowest deposition of $\mathrm{NH}_{\mathrm{x}}$.

Such differences are not unexpected, as chemical mechanisms, deposition process, and dispersion processes are quite different in the four CTMs. As a further illustration of this, Fig. 4 shows concentrations and dry depositions of $\mathrm{NO}_{2}$ and $\mathrm{NH}_{3}$ along the north-south European transect at $10^{\circ} \mathrm{E}$ indicated in Fig. 1 (this transect was chosen as it passes through many different pollution climates, from the polluted Po Valley in the south, through high $\mathrm{NH}_{3}$ areas in NW Europe, to relatively clean areas in the north). Differences are clearly substantial, with, for example, EMEP showing far lower deposition rates of $\mathrm{NO}_{2}$ compared to especially MATCH and
SILAM, despite relatively high $\mathrm{NO}_{2}$ concentrations. This particular feature likely reflects the EMEP model's use of lower deposition velocities as a proxy for an $\mathrm{NO}_{2}$ compensation point (this behaviour is switched on when there is no explicit modelling of soil NO emissions). Such model assumptions can have large impacts on individual species but a lower impact on total $\mathrm{Nr}$ concentrations or depositions.

\subsection{Scenario runs}

Figure 5a shows the 3CTM-ensemble mean $\mathrm{NO}_{\mathrm{y}}$ deposition from the three RCA3-driven European-scale CTMs, with levels of around $5-10 \mathrm{~kg}(\mathrm{~N}) \mathrm{ha}^{-1}$ in central Europe, declining to less than $2 \mathrm{~kg}(\mathrm{~N}) \mathrm{ha}^{-1}$ in northern areas. Figure $5 \mathrm{~b}$ shows the changes in $\mathrm{NO}_{\mathrm{y}}$ deposition arising from climate change only (E05-M00-BC2). Levels of $\mathrm{NO}_{\mathrm{y}}$ deposition increase in central Europe to some extent (ca. $0.1-0.5 \mathrm{~kg}(\mathrm{~N}) \mathrm{ha}^{-1}$ ), but decrease in, for example, the Nordic area by a similar amount. Figure $5 \mathrm{c}$ shows the corresponding changes brought about by scenario E05-M50-BC3, in which boundary conditions are also allowed to change to 2050 levels, but the picture is little changed from the effects of climate change alone. Figure $5 \mathrm{~d}$ shows much more dramatic changes in the case of E50-M50-BC3, where European emissions are set to the 2050 levels. $\mathrm{NO}_{\mathrm{y}}$ deposition is reduced by more than $0.5 \mathrm{~kg}(\mathrm{~N}) \mathrm{ha}^{-1}$ over almost all of Europe, and more than $4 \mathrm{~kg}(\mathrm{~N}) \mathrm{ha}^{-1}$ in central areas.

Figure 6 provides similar results for $\mathrm{NH}_{\mathrm{x}}$ deposition. The results of the climate and climate+boundary-conditions simulations are rather similar in magnitude to the equivalent results for $\mathrm{NO}_{\mathrm{y}}$ species, although climate change seems to increase $\mathrm{NH}_{\mathrm{x}}$ deposition in northern and eastern regions to a greater extent than $\mathrm{NO}_{\mathrm{y}}$. In broad terms, these climaterelated runs seem to reflect the pattern of rainfall change (Fig. S2d, Supplement) to some extent. The most dramatic difference, though, is with Fig. 6d, which shows that future 


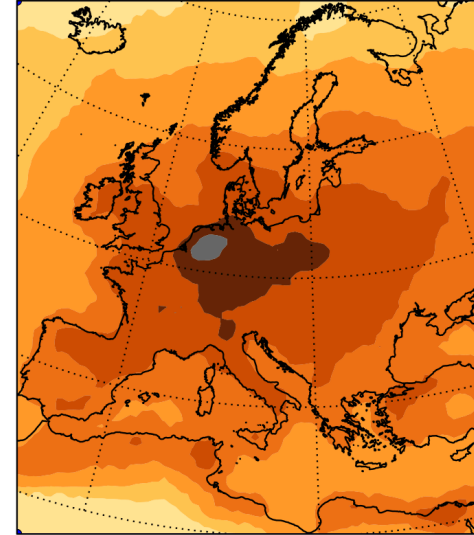

(a) DEHM

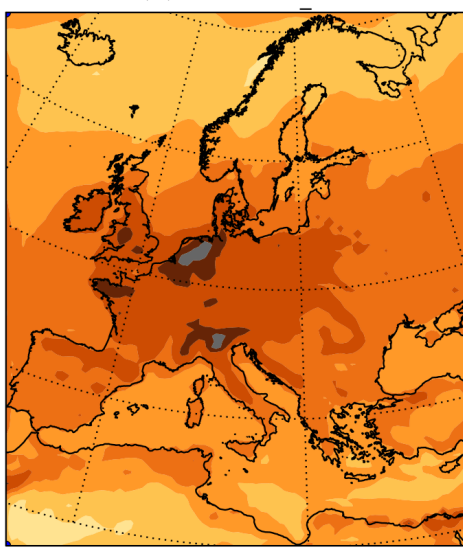

(c) MATCH

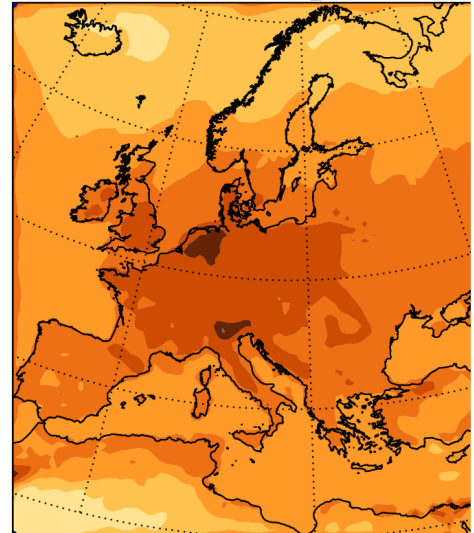

(b) EMEP MSC-W

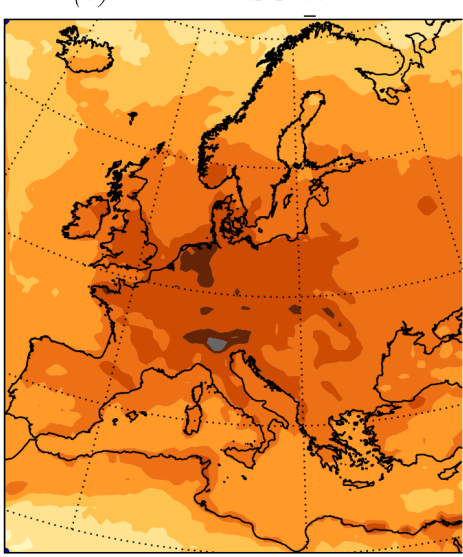

(d) SILAM

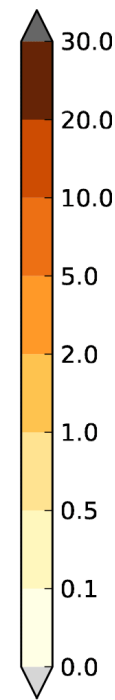

Figure 3. Calculated deposition of total $\mathrm{Nr}$ from the four CTMs. Results given as $20 \mathrm{yr}$ means (1990-2009) for the base case (E05-M00-BC1). Unit: $\mathrm{kg}(\mathrm{N}) \mathrm{ha}^{-1}$.
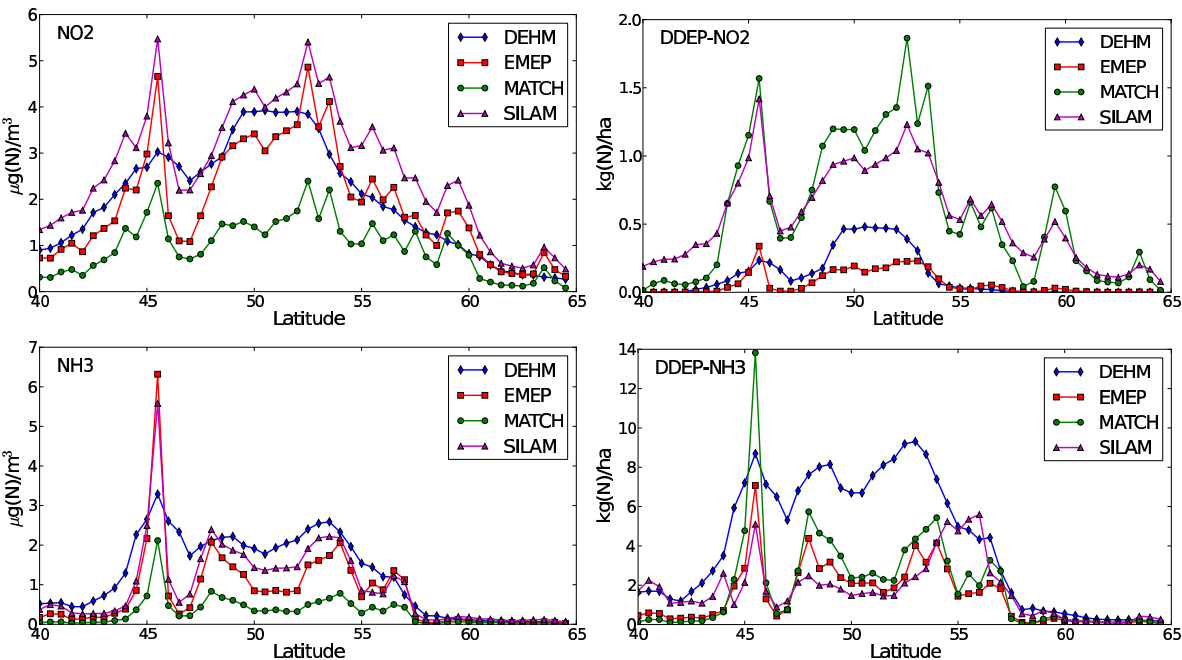

Figure 4. Examples of model variability for two compounds. Calculated base-case concentrations (left column, $\mu \mathrm{g}(\mathrm{N}) \mathrm{m}^{-3}$ ) and dry depositions (right column, $\mathrm{kg}(\mathrm{N}) \mathrm{ha}^{-1}$ ) along the $10^{\circ} \mathrm{E}$ transect (cf. Fig. 1) for $\mathrm{NO}_{2}$ (top row) and $\mathrm{NH}_{3}$ (bottom row). 


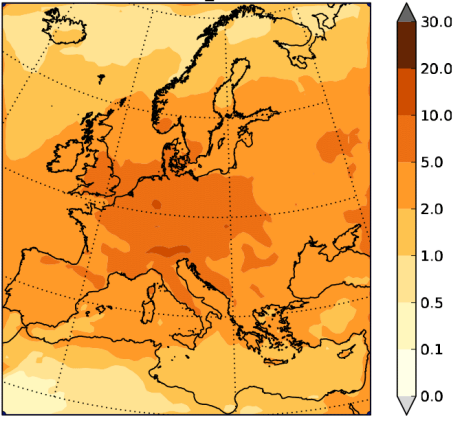

(a) Base-case, TDEP-NOy

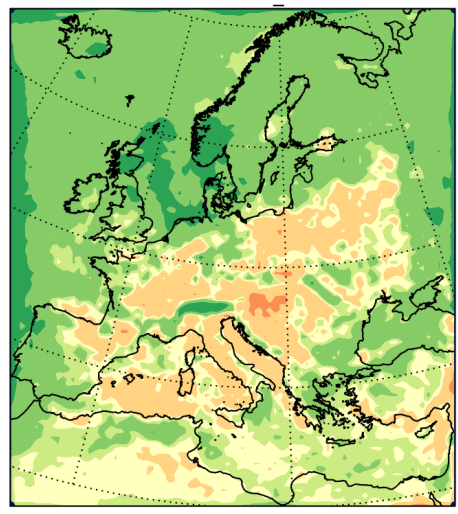

(c) $\triangle \mathrm{TDEP}-\mathrm{NOy}$, climate+BCs

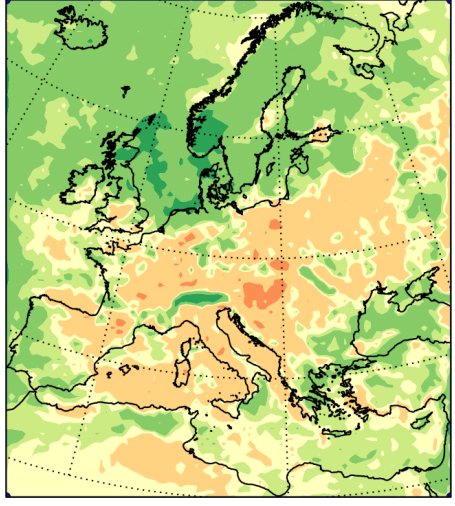

(b) $\triangle$ TDEP-NOy, climate

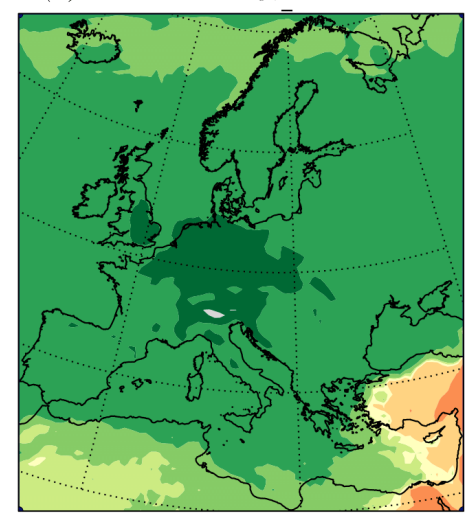

(d) $\triangle$ TDEP-NOy, Future

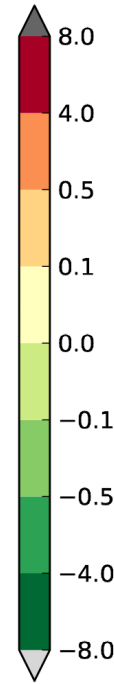

Figure 5. Results from the $3 \mathrm{CTM}$ ensemble (see text), for (a) base-case deposition of $\mathrm{NO}_{\mathrm{y}}\left(\mathrm{TDEP}_{\mathrm{NO}}\right.$, innermost legend), and changes

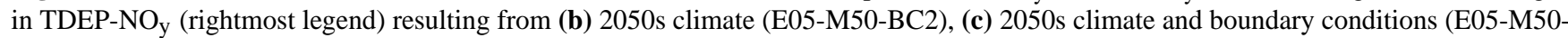
$\mathrm{BC} 3$ ), and (d) 2050s emissions, climate and boundary conditions (E50-M50-BC3). Unit: $\mathrm{kg}(\mathrm{N}) \mathrm{ha}^{-1}$.

emissions will substantially increase $\mathrm{NH}_{\mathrm{x}}$ deposition in large parts of Europe (discussed further below).

Figure 7 summarises the results of these calculations, presenting average depositions over the EU28 ${ }^{+}$domain (cf. Table 2) from all four models, and four scenarios. As noted above in the spatial maps, the most dramatic changes are only seen with the E50-M50-BC3 scenario, in which emissions from the year 2050 are used. Dry and wet deposition of $\mathrm{NO}_{\mathrm{y}}$ decreases significantly in all models. Dry deposition of $\mathrm{NH}_{\mathrm{x}}$ increases to some extent in all models, whereas wet deposition of $\mathrm{NH}_{\mathrm{X}}$ shows smaller changes.

The similarity of results from the three scenarios using 2005 emissions from each model is unsurprising, given that emissions are not changed, and the domain is large, but differences are much more apparent when looking at smaller regions or particular locations. In order to visualise this better, Figs. 8 and 9 show the $\mathrm{Nr}$ deposition and changes in $\mathrm{Nr}$ deposition along the same north-south transect as used in Fig. 4. In Fig. 8, the densely populated (and high-emission, especially for $\mathrm{NH}_{3}$ ) Italian Po Valley area, starting around $45^{\circ} \mathrm{N}$, is clearly visible in the three RCA3-driven CTMs. The ECHAM5-driven DEHM model shows smoother deposition patterns, but all models show high $\mathrm{Nr}$ deposition from around $45^{\circ} \mathrm{N}$ to around $58^{\circ} \mathrm{N}$ (between Denmark and Norway). Differences in $\mathrm{Nr}$ deposition are greatest for the dry-deposition components along this transect, with, for example, a factor of 3 between the lowest and highest values in mid-latitudes.

Figure 9 shows the differences between the future case (E50-M50-BC3) and base case for the same components. The models are seen to behave in rather similar ways for total and wet deposition, with substantial reductions (of up to $\left.10 \mathrm{~kg}(\mathrm{~N}) \mathrm{ha}^{-1}\right)$ in the Po Valley region. For dry deposition, the picture is more complex, with larger differences between models, and with some regions experiencing reduced $\mathrm{Nr}$ deposition, while others (e.g. around $55^{\circ} \mathrm{N}$ ) experience increased deposition.

It can be noted that the magnitude and distribution of changes in $\mathrm{Nr}$ deposition over Europe is sensitive to the climate projection that is used. Engardt and Langner (2013) compared three different climate projections (including the one used here) using the MATCH model and found changes due to climate change by 2050 of less than $\pm 1 \mathrm{~kg}(\mathrm{~N})$ ha for both $\mathrm{NH}_{\mathrm{y}}$ and $\mathrm{NH}_{\mathrm{x}}$. These changes are comparable to the ensemble mean changes presented here. Hedegaard et al. 


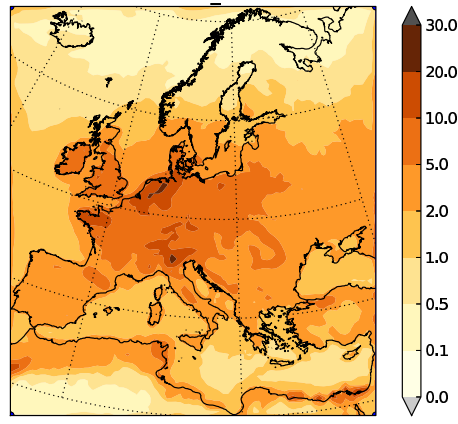

(a) Base-case, TDEP-NHx

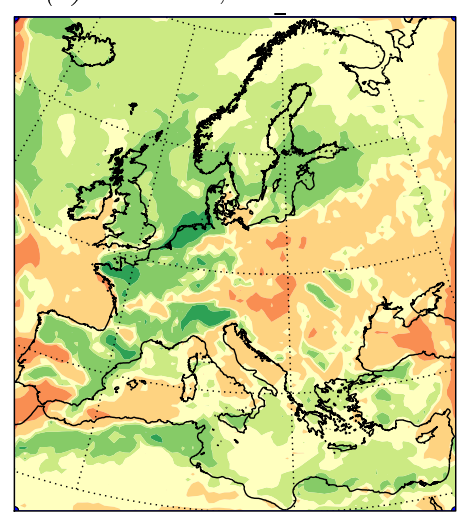

(c) $\triangle \mathrm{TDEP}-\mathrm{NHx}$, climate+BCs

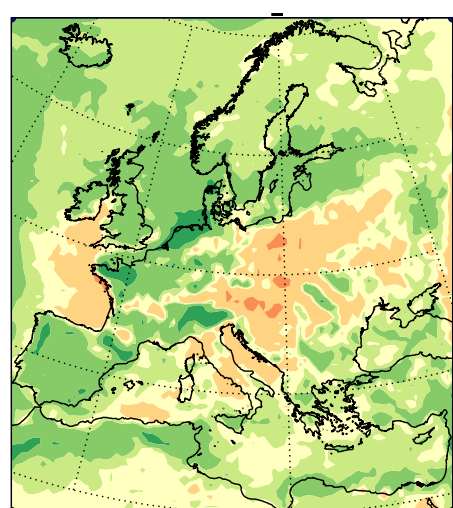

(b) $\triangle$ TDEP-NHx, climate

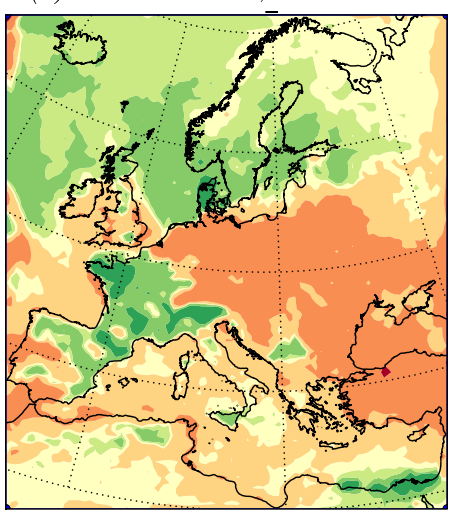

(d) $\triangle \mathrm{TDEP}-\mathrm{NHx}$, Future

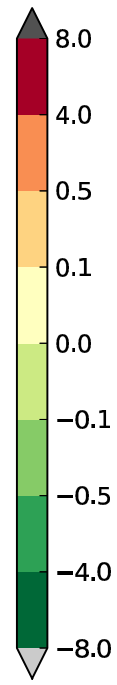

Figure 6. Same as Fig. 5 but for reduced nitrogen, $\mathrm{NH}_{\mathrm{X}}$.
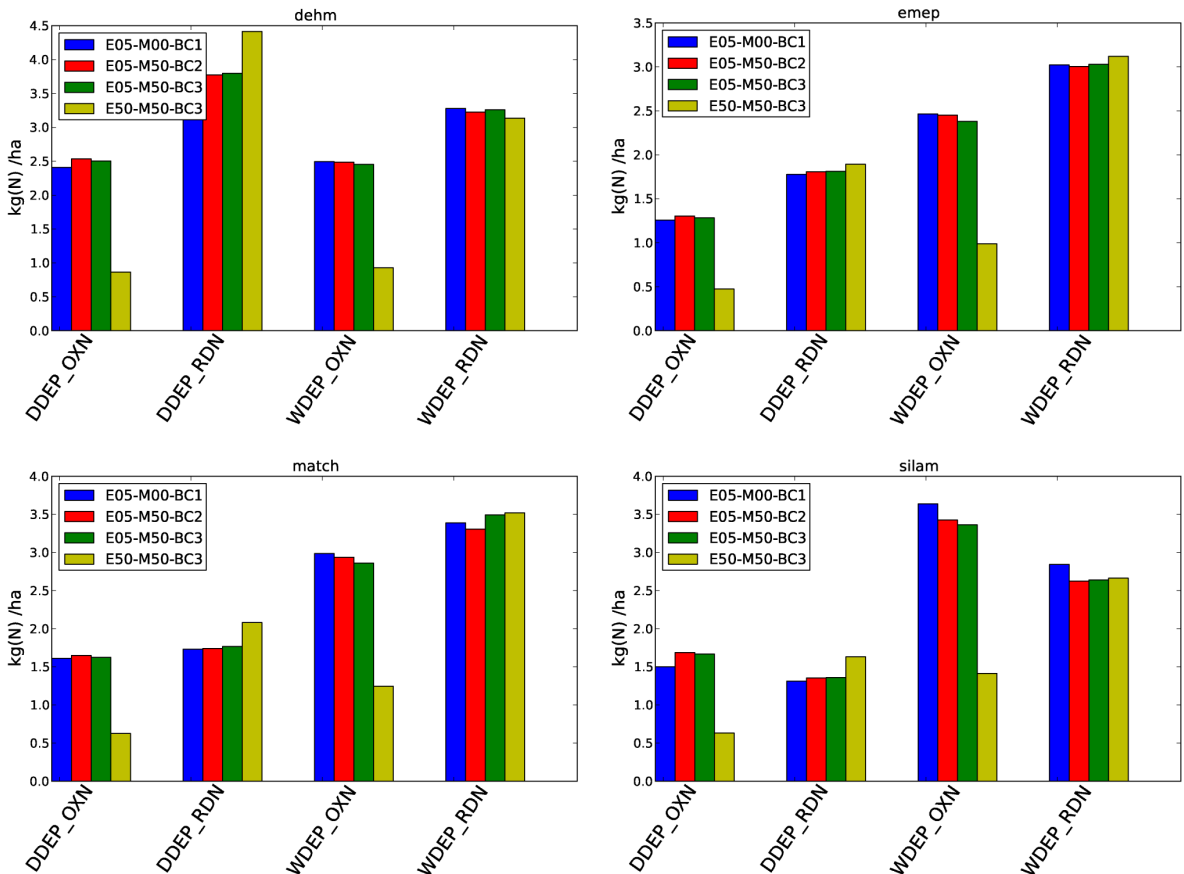

Figure 7. Calculated deposition components of $\mathrm{Nr}$ from four CTMs and four scenarios for the EU28 ${ }^{+}$region. Blocks of bars distinguish wet and dry deposition (WDEP, DDEP) and $\mathrm{NO}_{\mathrm{y}}$ and $\mathrm{NH}_{\mathrm{x}}$ components. 
Table 6. Excess Nr deposition over $10 \mathrm{~kg}(\mathrm{~N}) \mathrm{ha}^{-1} \mathrm{yr}^{-1}$ for the four CTMs in the EU28 ${ }^{+}$region.

\begin{tabular}{|c|c|c|c|c|c|c|c|c|c|c|c|c|}
\hline \multirow[t]{2}{*}{ Model } & \multicolumn{2}{|c|}{ E05-M00-BC1 } & \multicolumn{2}{|c|}{ E05-M50-BC2 } & \multicolumn{2}{|c|}{ E05-M50-BC3 } & \multicolumn{2}{|c|}{ E50-M50-BC3 } & \multicolumn{2}{|c|}{ E50X20-M50-BC3 } & \multicolumn{2}{|c|}{ E50X30-M50-BC3 } \\
\hline & $f_{10}$ & $E_{10}$ & $f_{10}$ & $E_{10}$ & $f_{10}$ & $E_{10}$ & $f_{10}$ & $E_{10}$ & $f_{10}$ & $E_{10}$ & $f_{10}$ & $E_{10}$ \\
\hline DEHM & 56 & 3.58 & 56 & 3.75 & 55 & 3.74 & 38 & 2.09 & 45 & 3.18 & - & - \\
\hline EMEP & 37 & 1.44 & 38 & 1.53 & 37 & 1.50 & 19 & 0.55 & 28 & 1.01 & 32 & 1.29 \\
\hline МАTCH & 43 & 2.41 & 43 & 2.44 & 44 & 2.46 & 28 & 1.04 & - & - & - & - \\
\hline SILAM & 40 & 1.82 & 39 & 1.76 & 39 & 1.73 & 18 & 0.48 & - & - & - & - \\
\hline
\end{tabular}

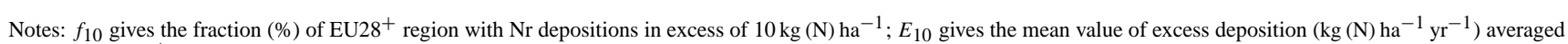
across the EU $28^{+}$region.

Table 7. Statistics of detailed critical load exceedances in the EU28 ${ }^{+}$region, EMEP MSC-W model.

\begin{tabular}{lcc}
\hline Scenario & $\begin{array}{c}\text { Area exceeded } \\
f_{\mathrm{CL}}(\%)\end{array}$ & $\begin{array}{c}\text { Mean exceedance } \\
E_{\mathrm{CL}}\left(\mathrm{kg}(\mathrm{N}) \mathrm{ha}^{-1} \mathrm{yr}^{-1}\right)\end{array}$ \\
\hline E05-M00-BC1 & 64.1 & 3.81 \\
E05-M50-BC2 & 64.4 & 3.83 \\
E05-M50-BC3 & 64.1 & 3.78 \\
E50-M50-BC3 & 49.8 & 1.89 \\
E50X20-M50-BC3 & 54.9 & 2.57 \\
E50X30-M50-BC3 & 56.9 & 2.94 \\
\hline
\end{tabular}

(2013) reported a general reduction in the $\mathrm{Nr}$ deposition over Europe above $0.2 \mathrm{~kg}(\mathrm{~N})$ ha due to climate change in the period 1990 to 2090 using the hemispheric DEHM model. This could be compared to the case with changing BCs and changing climate in this study, which gives an increase in central/southern Europe for $\mathrm{NH}_{\mathrm{y}}$ and a more widespread increase for $\mathrm{NH}_{\mathrm{x}}$. These differences in results are, however, small enough to be explained by differences in the climate projection used. Engardt and Langner (2013) also reported changes in $\mathrm{Nr}$ deposition due to emission changes until 2050 using the RCP4.5 scenario. The reductions in deposition are comparable to those reported here for $\mathrm{NH}_{\mathrm{y}}$, but for $\mathrm{NH}_{\mathrm{x}}$ the distribution of the changes are different, primarily due to differences in the emission data.

\subsection{Changes in $\mathrm{NH}_{\mathrm{x}}$ partitioning}

Results presented so far have dealt with groups of either oxidised, reduced or total depositions of $\mathrm{Nr}$ compounds. Figure 10 illustrates changes for particular compounds, from one model (EMEP). The oxidised compounds $\mathrm{NO}, \mathrm{NO}_{2}$ and nitrate all show relatively straightforward reductions, as expected from the emissions change. PAN is also reduced, but not to the same extent, and PAN also shows more sensitivity to the climate and boundary condition changes than other $\mathrm{NO}_{\mathrm{y}}$ species. The most interesting changes are seen for the reduced compounds - with substantial increases in gaseous $\mathrm{NH}_{3}$ and substantial decreases in particulate ammonium. This effect was also noted by Engardt and Langner (2013) and is caused by the fact that, in the year 2050 sce-
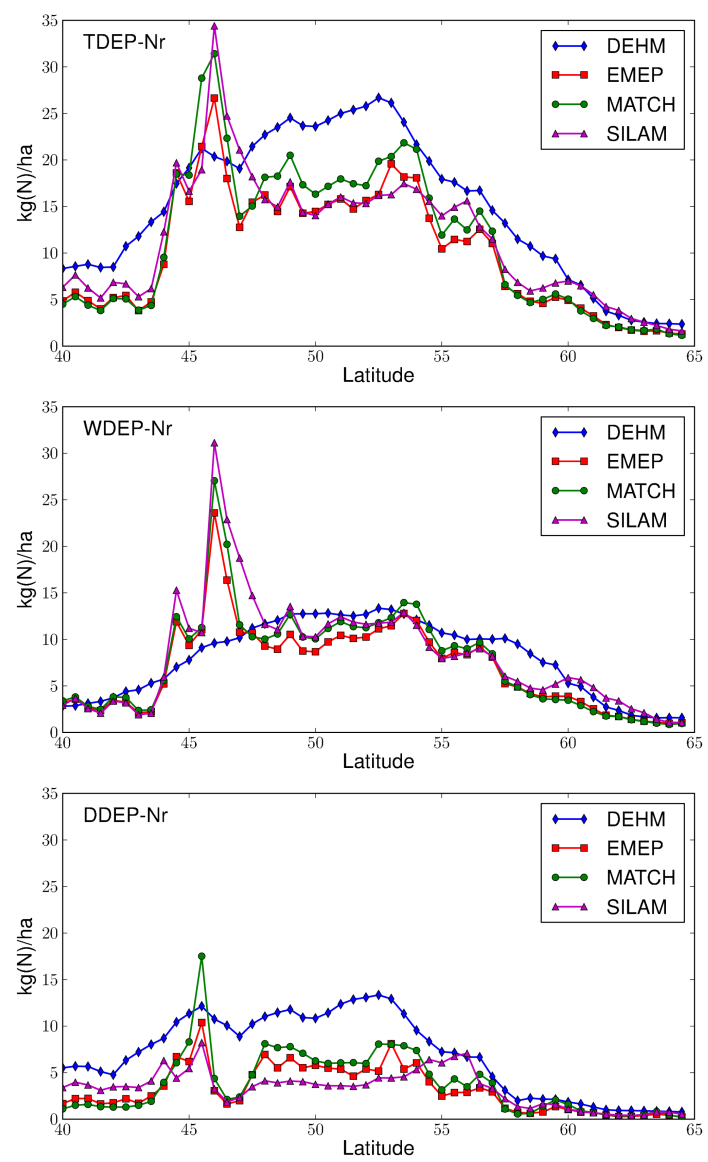

Figure 8. Calculated base-case deposition along the $10^{\circ}$ east transect (cf. Fig. 1), for total $\mathrm{Nr}$ deposition (top), wet deposition (middle), dry deposition (bottom).

narios, there is too little sulfate and even too little $\mathrm{HNO}_{3}$ to react with $\mathrm{NH}_{3}$. This effect is further illustrated in Fig. 11, which shows the changes in (a) $\mathrm{NH}_{3}$ deposition and (b) total $\mathrm{NH}_{\mathrm{x}}$ deposition between the base and future case. Comparing these changes to Fig. $2 b$, it is clear that while the total $\mathrm{NH}_{\mathrm{x}}$ deposition change is quite similar to that of the emissions, the deposition changes in $\mathrm{NH}_{3}$ are clearly much higher than the emission changes in much of Europe. (One caveat should be expressed with regard to Fig. 10. According to this 

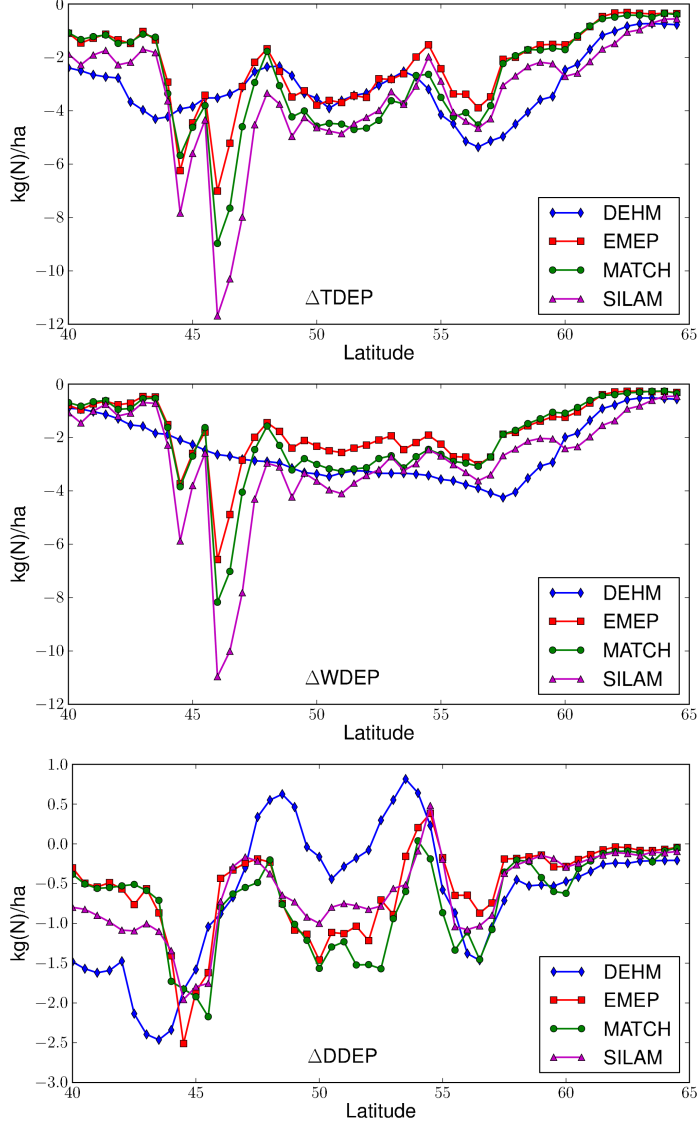

Figure 9. Calculated changes in total, wet and dry deposition of $\mathrm{Nr}$, future case (E50-M5-BC3) minus base case (E05-M00-BC1). Same transect as Fig. 8 .

figure, the sum, $\mathrm{NH}_{\mathrm{x}}$, of $\mathrm{NH}_{3}+\mathrm{NH}_{4}^{+}$is approximately constant from the year 2000s to the 2050s scenario. However, Fig. 10 shows averages over a large area. In fact, as seen in Fig. 11, the deposition of $\mathrm{NH}_{\mathrm{x}}$ decreases in most parts of western Europe, especially France, and increases in many parts of central and eastern Europe; see also Fig. $2 b$ for emissions. The EU28+ area includes areas in both regimes.)

There are of course many issues with the modelling of ammonia exchange, with clear model limitations associated with the lack of bidirectional exchange in these CTMs (Bash et al., 2013; Flechard et al., 2013; Wichink-Kruit et al., 2010). This will be discussed further in the conclusions. The results of the increased $\mathrm{NH}_{3}$ emissions associated with the final two scenarios are discussed below in the context of critical load exceedances.

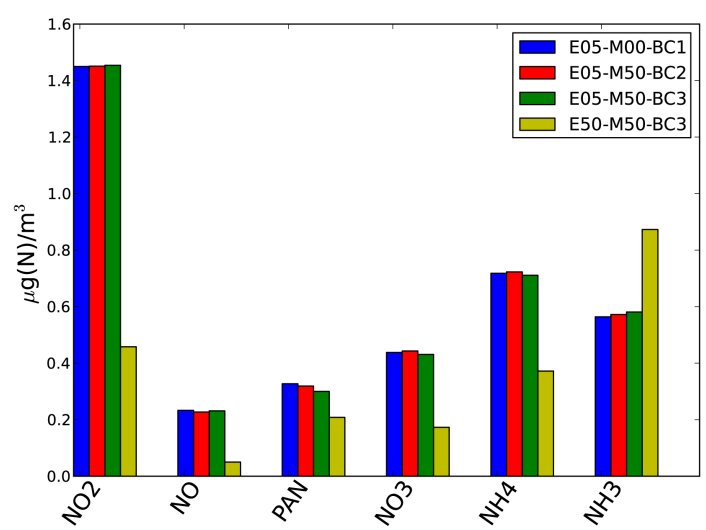

Figure 10. Calculated concentrations of major $\mathrm{Nr}$ species from the EMEP MSC-W model for four scenarios. EU28 ${ }^{+}$region.

\section{Exceedances of critical loads}

A critical load (CL) is defined as a quantitative estimate of an exposure to one or more pollutants below which significant harmful effects on specified sensitive elements of the environment do not occur according to present knowledge (Nilsson and Grennfelt, 1988). If a deposition is higher than the critical load at a site, the CL is said to be exceeded, and in this paper, exceedances due to total annual $\mathrm{N}$ deposition are calculated for the EU28 ${ }^{+}$region. Dentener et al. (2006) and Lamarque et al. (2005) used a fixed, ecosystem-independent CL value of $1 \mathrm{~g}(\mathrm{~N}) \mathrm{m}^{-2} \mathrm{yr}^{-1}\left(10 \mathrm{~kg}(\mathrm{~N}) \mathrm{ha}^{-1} \mathrm{yr}^{-1}\right)$, as this allowed comparison across multiple models. Before we consider calculations of "real" ecosystem-dependent CL values with the EMEP model, we present first also our multi-model comparison using this simple $10 \mathrm{~kg}(\mathrm{~N}) \mathrm{ha}^{-1}$ value. Table 6 compares the area of exceedance of $10 \mathrm{~kg}(\mathrm{~N}) \mathrm{ha}^{-1} \mathrm{yr}^{-1}\left(f_{10}\right)$ and the average exceedance $\left(E_{10}\right)$ for all scenarios used in this study, including the X20 and X30 variations of the future case. Table 6 shows that the three European-scale CTMs give similar areas of exceedance of the $10 \mathrm{~kg}(\mathrm{~N}) \mathrm{ha}^{-1} \mathrm{yr}^{-1}$ level (ca. $40 \%$ ) in the base case, although MATCH predicts considerably more excess than EMEP. DEHM shows a much larger area of exceedance, and excess, in this case. Similar to results presented above for total depositions, the effect of the E05-M50-BC2 and E05-M50-BC3 scenarios is relatively small. The E50-M50-BC3 scenario shows dramatic reductions in $f_{10}$ and $E_{10}$ compared to the base case.

The DEHM and EMEP models were used for the future scenario with $20 \%$ increased $\mathrm{NH}_{3}$ emissions (E50X20-M50BC3). Although exceedances are still below the base-case values, the increased $\mathrm{NH}_{3}$ has a large impact, with 50 and $80 \%$ increases in $E_{10}$ compared to the standard future scenario E50-M50-BC3. The EMEP model calculation of the $30 \% \mathrm{NH}_{3}$ increase brings $E_{10}$ values almost back to the 2005 levels. 


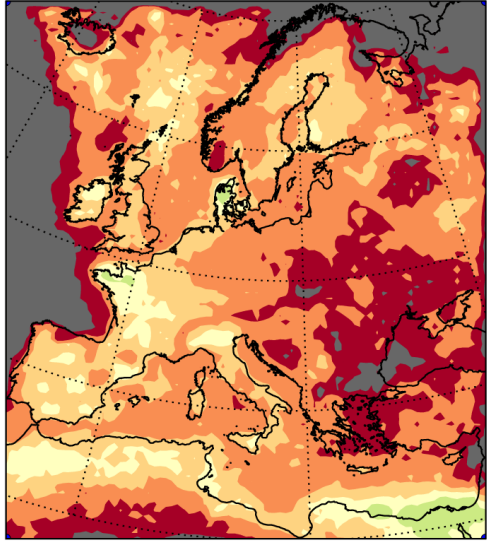

(a) $\mathrm{NH}_{3}$

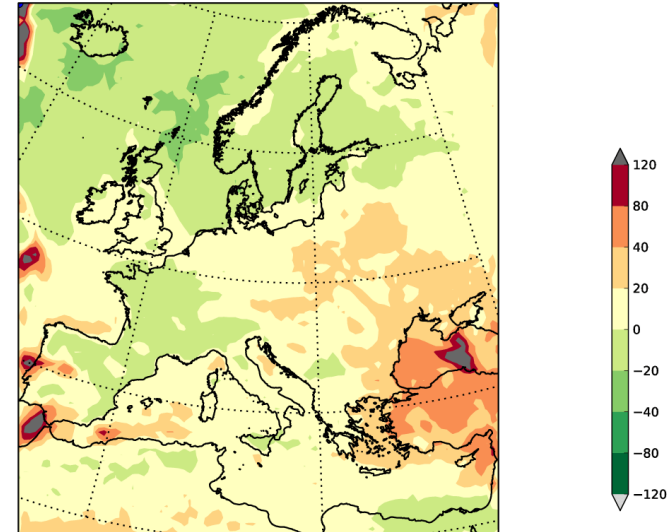

(b) $\mathrm{NHx}$

Figure 11. Changes in total deposition (\%), from 2005 to 2050, for $\mathrm{NH}_{3}$ and $\mathrm{NH}_{\mathrm{X}}$. Results from the $3 \mathrm{CTM}$ ensemble. The colour scale is identical to that used for emission changes in Fig. 2.

As noted above, the use of the fixed $10 \mathrm{~kg}(\mathrm{~N}) \mathrm{ha}^{-1} \mathrm{yr}^{-1}$ threshold is a simple proxy for CLs. Within the Convention for the Long-range Transboundary Air Pollution (CLRTAP, www.unece.org/env/lrtap), for which EMEP provides ecosystem-specific deposition data, CL values are assessed in a much more realistic way. Critical loads are calculated for different receptors (e.g. terrestrial ecosystems, aquatic ecosystems), and "sensitive elements" can be any part (or the whole) of an ecosystem or ecosystem process. Critical loads have been defined for several pollutants $(\mathrm{S}, \mathrm{N}$, heavy metals), but here we restrict ourselves to CLs defined to avoid the eutrophying effects of $\mathrm{N}$ deposition (critical load of nutrient $\mathrm{N}, \mathrm{CL}_{\text {nut }}(\mathrm{N})$ ). The $\mathrm{CL}$ for a site is either derived empirically or calculated from a simple steady-state mass balance equation(s) that link a chemical criterion (e.g. an acceptable $\mathrm{N}$ concentration in soil solution that should not be exceeded) with the corresponding deposition value(s). Methods to compute CLs are summarised in the so-called Mapping Manual (UNECE, 2004; De Vries and Posch, 2003).

Values of $\mathrm{CL}_{\text {nut }}(\mathrm{N})$ are calculated using the current critical load database held at the Coordination Centre for Effects (CCE; Posch et al., 2011, 2012) and used in supporting EU and CLRTAP negotiations on emission reductions (Hettelingh et al., 1995, 2001; Reis et al., 2012). The single exceedance number computed for a grid cell (or any other region) is the so-called average accumulated exceedance (AAE), defined as the weighted mean of all ecosystems within the grid, with the weights being the respective ecosystem areas (see Posch et al., 2001).

Figure 12 shows the grid AAE values as derived from the EMEP model ecosystem-specific $\mathrm{N}$ deposition data for the six scenarios (cf. Table 1). Although reductions in exceedance are especially seen in the E50-M50-BC3 scenario compared to the base case, patterns do not vary dramatically, and there is still widespread exceedance even for this most stringent scenario. To better summarise these scenarios, the

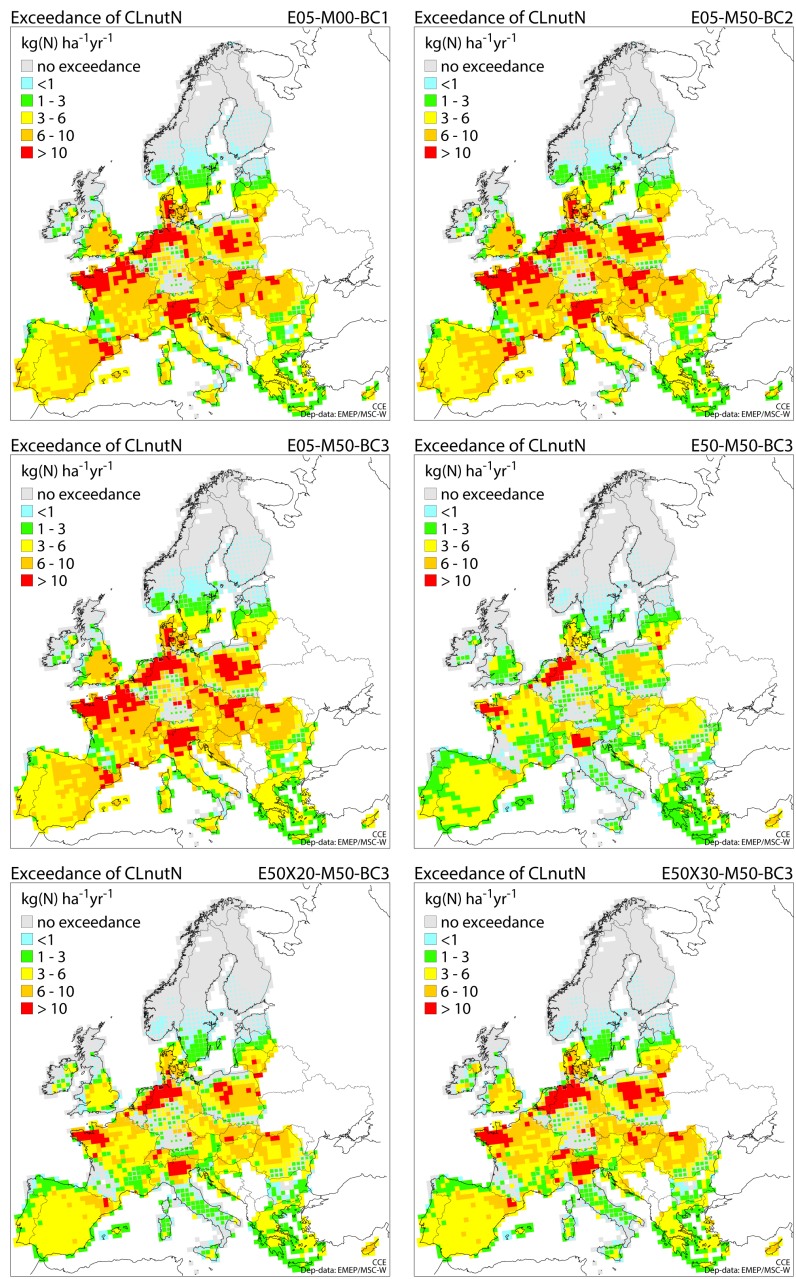

Figure 12. Exceedances of the critical loads for nutrient nitrogen $\left(\mathrm{CL}_{\text {nut }}(\mathrm{N})\right)$ in the $\mathrm{EU} 28^{+}$region, EMEP MSC-W model, for the six scenarios. 


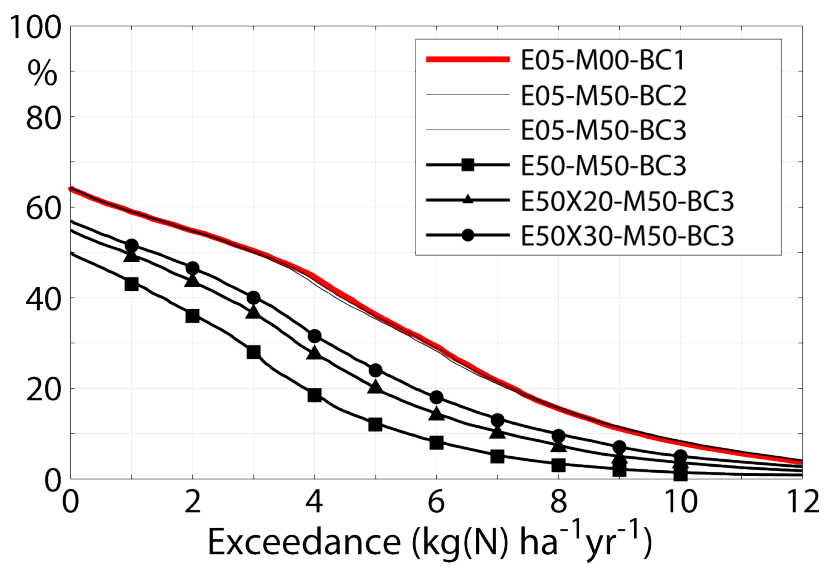

Figure 13. Inverse cumulative distribution functions of exceedances (AAE) of $\mathrm{CL}_{\text {nut }}(\mathrm{N})$ in $\mathrm{EU} 28^{+}$for the six scenarios using the EMEP MSC-W model. Note that scenarios 2 and 3 (black thin lines) barely differ from the base scenario.

inverse cumulative distribution functions of the exceedances are shown in Fig. 13. Exceedances for the three scenarios distinguished only by meteorology and/or boundary condition are similar (see also Table 7 for some statistics), whereas the change in emissions has clearly the largest overall impact. Exceedance levels for the X20 and X30 versions of the 2050 scenarios are well below the scenarios representative of the 2000s but substantially greater than the E50-M50-BC3 case.

\section{Conclusions}

This study has compared predictions of nitrogen deposition from four chemical transport models (CTMs) for both current conditions and future scenarios. All models were driven by the same basic emission system (except for biogenic VOC, which was model-specific). The three European-scale CTM models were driven by the same regional climate model (RCA3) meteorology, and also by a common set of boundary conditions given by the fourth (hemispheric-scale) CTM, DEHM. One base case and three main scenario cases were designed to explore the impact of climate, boundary conditions and emissions changes on European $\mathrm{N}$ deposition. Two further speculative scenarios were also explored with 1-2 models.

As all of these models have been driven by data from global and/or regional climate models, rather than "real" NWP meteorology, it is not possible to directly compare to measurements. However, we have compared modelled and observed data in a statistical way, and in general the model results seem comparable to the observations (most components were predicted within $30 \%$ ). Some significant discrepancies were found, which in the case of the DEHM model could be ascribed to problems caused by the large-scale climate data that are not normally seen in typical DEHM usage.
Deposition estimates from the models were compared as large-scale average, and illustrated for a north-south transect. Although modelled total deposition was rather similar among the models (presumably reflecting prescribed emissions), differences for wet or dry contributions were typically of the order of $30 \%$. For specific locations (as illustrated along our transect), or even more so for specific compounds, differences can be much greater. Of course, such differences are not unexpected since many aspects of $\mathrm{Nr}$ modelling are not well constrained. For example, there is a lack of data which could specify the proper partitioning of $\mathrm{NO}_{\mathrm{y}}$ between $\mathrm{HNO}_{3}$ and fine or coarse nitrate. Further, large variability in drydeposition rates (with factors of 2-3) is known to exist among deposition modules (Flechard et al., 2011). This variability is a reflection of the difficulties in measuring deposition rates (e.g. Fowler et al., 2009; Pryor et al., 2008) and also of complications due to bidirectional fluxes (discussed below) and chemical interactions. There is thus a lack of data with which to constrain dry-deposition fluxes, and this is reflected in the differences in modelled $\mathrm{Nr}$ depositions found in this study.

Other results from the model comparison can be summarised:

- All models clearly show that the impact of emissions changes is much greater than the impact of climate change alone, or of both climate change and emissions changes outside of Europe.

- The biggest difference between the models is for predictions of individual $\mathrm{N}$ compounds. Predictions for wet and total deposition were, however, broadly consistent, although the three fine-scale models resolve European emission areas and spatial changes better than the hemispheric-scale model.

- The model predictions for 2050 generally follow the emission changes, with significant reductions in oxidised $\mathrm{N}$ concentrations and depositions, but slightly increasing levels of reduced $\mathrm{N}$ deposition.

- For reduced nitrogen, the 2050 emissions are predicted to cause a large increase in gaseous $\mathrm{NH}_{3}$ deposition in most of Europe, but with large corresponding decreases in ammonium. This difference is caused by the much reduced levels of both $\mathrm{SO}_{2}$ and $\mathrm{HNO}_{3}$ in the future atmosphere, preventing the formation of ammonium sulfates or nitrates.

- The ecosystem-specific depositions of the EMEP model were used to assess the extent to which critical loads (CLs) for ecosystems were exceeded in the different scenarios. The results showed that CLs were essentially only sensitive to scenarios that change emissions. In the 2050 future case, exceedances were substantially reduced, but were still widespread, with exceedances of $\mathrm{CL}$ in $50 \%$ of ecosystems 
(mean exceedance of $1.89 \mathrm{~kg}(\mathrm{~N}) \mathrm{ha}^{-1} \mathrm{yr}^{-1}$, down from $3.81 \mathrm{~kg}(\mathrm{~N}) \mathrm{ha}^{-1} \mathrm{yr}^{-1}$ in the base case).

- Two further scenarios were explored, involving 20 and $30 \%$ increases in $\mathrm{NH}_{3}$ emissions above expected 2050 levels, which reflects the possibility that the emission rates might respond to climate change more than accounted for in the emissions inventory. Comparison of these runs against the CL data shows that even a $30 \%$ increase in $\mathrm{NH}_{3}$ will not bring exceedances back to 2000s levels, but such climate-induced increases cause CL exceedances that are substantially larger than those of the standard 2050 emission scenario (worst case here $57 \%$ of areas in excess, with $2.9 \mathrm{~kg}(\mathrm{~N}) \mathrm{ha}^{-1} \mathrm{yr}^{-1}$ mean exceedance).

Major problems remain in predicting $\mathrm{NH}_{3}$ deposition in particular. With regard to emissions control strategies, the increased $\mathrm{NH}_{3}$ deposition noted above (and in, for example, Engardt and Langner, 2013) implies that local control measures might become more effective. On the other hand, Engardt and Langner (2013) also estimated longer lifetimes of $\mathrm{S}$ and $\mathrm{NH}_{\mathrm{y}}$ compounds in the future, thus increasing the international transport of some particles. Wichink-Kruit et al. (2012) also showed that inclusion of bidirectional exchange increases the transport distance of $\mathrm{NH}_{\mathrm{x}}$, which would affect any predictions of $\mathrm{Nr}$ deposition and CL exceedance. Indeed, the complexities of bidirectional exchange have been noted in many papers (e.g. Sutton et al., 1995; Nemitz and Sutton, 2004; Fowler et al., 2009; Massad et al., 2010; Flechard et al., 2013), and some CTMs have attempted to include such exchange (e.g. Wichink-Kruit et al., 2010; Bash et al., 2013). However, such modelling is limited by many factors, including process uncertainties (Massad et al., 2010; Flechard et al., 2013), problems of sub-grid heterogeneity (e.g. Loubet et al., 2001, 2009) and lack of necessary and accurate input data.

Still, the overriding conclusion of this paper is probably robust: reducing future deposition of $\mathrm{Nr}$ in Europe is mainly dependent upon the way in which future $\mathrm{NH}_{3}$ emissions develop. The new recognition that climate change may influence emissions much more than currently accounted for in official inventories makes it even more important that methods to deal with $\mathrm{NH}_{3}$ emissions are improved.

\section{The Supplement related to this article is available online at doi:10.5194/acp-14-6995-2014-supplement.}

Acknowledgements. This study was initiated and mainly supported by the Nordic Council of Ministers (EnsCLIM project, NMR no. KoL-10-04) and the EU project ECLAIRE (project no. 282910). Further support came from the EU projects MEGAPOLI (no. 212520), PEGASOS (no. 265148), TRANSPHORM (no. 243406), NMR FAN (kol-1204) and Danish
ECOCLIM projects, and the Swedish Environmental Protection Agency through the research programme CLEO (Climate Change and Environmental Objectives) as well as EMEP under the LRTAP UNECE Convention. The work is also a contribution to the Swedish Strategic Research Areas Modelling the Regional and Global Earth System (MERGE). Thanks are due to C. Heyes and Z. Klimont at IIASA for valuable help with the emission inventory processing.

Edited by: E. Nemitz

\section{References}

Aas, W., Tsyro, S., Bieber, E., Bergström, R., Ceburnis, D., Ellermann, T., Fagerli, H., Frölich, M., Gehrig, R., Makkonen, U., Nemitz, E., Otjes, R., Perez, N., Perrino, C., Prévôt, A. S. H., Putaud, J.-P., Simpson, D., Spindler, G., Vana, M., and Yttri, K. E.: Lessons learnt from the first EMEP intensive measurement periods, Atmos. Chem. Phys., 12, 8073-8094, doi:10.5194/acp-12-8073-2012, 2012.

Amann, M., Klimont, Z., and Wagner, F.: Regional and global emissions of air pollutants: recent trends and future scenarios, Annu. Rev. Env. Resour., 38, 31-55, doi:10.1146/annurevenviron-052912-173303, 2013.

Amann, M., Borken-Kleefeld, J., Cofala, J., Heyes, C., Klimont, Z., Rafaj, P., Purohit, P., Schoepp, W., and Winiwarter, W.: Future emissions of air pollutants in Europe - Current legislation baseline and the scope for further reductions, TSAP Report \#1, Institute for Applied Systems Analysis (IIASA), Laxenburg, Austria, http://webarchive.iiasa.ac.at/Admin/PUB/ Documents/XO-12-011.pdf, 2012.

Andersson, C. and Engardt, M.: European ozone in a future climate: importance of changes in dry deposition and isoprene emissions, J. Geophys. Res., 115, D02303, doi:10.1029/2008JD011690, 2010.

Andersson, C., Langner, J., and Bergstrom, R.: Interannual variation and trends in air pollution over Europe due to climate variability during 1958-2001 simulated with a regional CTM coupled to the ERA40 reanalysis, Tellus B, 59, 77-98, doi:10.1111/j.16000889.2006.00196.x, 2007.

Asman, W. A. H., Sørensen, L. L., Berkowicz, R., Granby, K., Nielsen, H., Jensen, B., Runge, E., Lykkelund, C., Gryning, S. E., and Sempreviva, A. M.: Dry deposition processes, Danish Environmental Protection Agency, Marine Research, 35, Copenhagen, Denmark, 1994.

Bash, J. O., Cooter, E. J., Dennis, R. L., Walker, J. T., and Pleim, J. E.: Evaluation of a regional air-quality model with bidirectional $\mathrm{NH}_{3}$ exchange coupled to an agroecosystem model, Biogeosciences, 10, 1635-1645, doi:10.5194/bg-10-1635-2013, 2013.

Binkowski, F. and Shankar, U.: The Regional Particulate Matter Model, 1. Model description and preliminary results, J. Geophys. Res., 100, 26191-26209, 1995.

Brandt, J., Silver, J. D., Frohn, L. M., Geels, C., Gross, A., Hansen, A. B., Hansen, K. M., Hedegaard, G. B., Skjoth, C. A., Villadsen, H., Zare, A., and Christensen, J. H.: An integrated model study for Europe and North America using the Danish Eulerian Hemispheric Model with focus on intercontinen- 
tal transport of air pollution, Atmos. Environ., 53, 156-176, doi:10.1016/j.atmosenv.2012.01.011, 2012.

Christensen, J. H.: The Danish Eulerian Hemispheric Model a three-dimensional air pollution model used for the Arctic, Atmos. Environ., 31, 4169-4191, 1997.

Colette, A., Granier, C., Hodnebrog, Ø., Jakobs, H., Maurizi, A., Nyiri, A., Bessagnet, B., D’Angiola, A., D’Isidoro, M., Gauss, M., Meleux, F., Memmesheimer, M., Mieville, A., Rouil, L., Russo, F., Solberg, S., Stordal, F., and Tampieri, F.: Air quality trends in Europe over the past decade: a first multimodel assessment, Atmos. Chem. Phys., 11, 11657-11678, doi:10.5194/acp-11-11657-2011, 2011.

Colette, A., Granier, C., Hodnebrog, Ø., Jakobs, H., Maurizi, A., Nyiri, A., Rao, S., Amann, M., Bessagnet, B., D’Angiola, A., Gauss, M., Heyes, C., Klimont, Z., Meleux, F., Memmesheimer, M., Mieville, A., Rouïl, L., Russo, F., Schucht, S., Simpson, D., Stordal, F., Tampieri, F., and Vrac, M.: Future air quality in Europe: a multi-model assessment of projected exposure to ozone, Atmos. Chem. Phys., 12, 1061310630, doi:10.5194/acp-12-10613-2012, 2012.

Cuvelier, C., Thunis, P., Vautard, R., Amann, M., Bessagnet, B., Bedogni, M., Berkowicz, R., Brandt, J., Brocheton, F., Builtjes, P., Carnavale, C., Coppalle, A., Denby, B., Douros, J., Graf, A., Hellmuth, O., Hodzic, A., Honore, C., Jonson, J., Kerschbaumer, A., de Leeuw, F., Minguzzi, E., Moussiopoulos, N., Pertot, C., Peuch, V., Pirovano, G., Rouil, L., Sauter, F., Schaap, M., Stern, R., Tarrason, L., Vignati, E., Volta, M., White, L., Wind, P., and Zuber, A.: CityDelta: a model intercomparison study to explore the impact of emission reductions in European cities in 2010, Atmos. Environ., 41, 189-207, 2007.

Dentener, F., Drevet, J., Lamarque, J. F., Bey, I., Eickhout, B., Fiore, A. M., Hauglustaine, D., Horowitz, L. W., Krol, M., Kulshrestha, U. C., Lawrence, M., Galy-Lacaux, C., Rast, S., Shindell, D., Stevenson, D., Van Noije, T., Atherton, C., Bell, N., Bergman, D., Butler, T., Cofala, J., Collins, B., Doherty, R., Ellingsen, K., Galloway, J., Gauss, M., Montanaro, V., Mueller, J. F., Pitari, G., Rodriguez, J., Sanderson, M., Solmon, F., Strahan, S., Schultz, M., Sudo, K., Szopa, S., and Wild, O.: Nitrogen and sulfur deposition on regional and global scales: a multimodel evaluation, Global Biogeochem. Cy., 20, GB4003, doi:10.1029/2005GB002672, 2006.

De Vries, W. and Posch, M.: Critical levels and critical loads as a tool for air quality management, in: Handbook of Atmospheric Science - Principles and Applications, edited by: Hewitt, C. N. and Jackson, A. V., chap. 20, Blackwell Science, Oxford, UK, 562-602, 2003.

Dore, A., Carslaw, D., Chemel, C., Derwent, R., Fisher, B., Griffiths, S., Lawrence, S., Metcalfe, S., Redington, A., Simpson, D., Sokhi, R., Sutton, P., Vieno, M., and Whyatt, J.: Evaluation and inter-comparison of acid deposition models for the UK, in: Air Pollution Modelling and its Application XXII, edited by: Steyn, D., Builtjes, P., and Timmermans, R., NATO Science for Peace and Security Series C. Environmental Security, Springer, Dordrecht, 32nd NATO/SPS International Technical Meeting, 505-509, 2013.

Emberson, L., Simpson, D., Tuovinen, J.-P., Ashmore, M., and Cambridge, H.: Towards a model of ozone deposition and stomatal uptake over Europe, EMEP MSC-W Note 6/2000, The Norwegian Meteorological Institute, Oslo, Norway, 2000a.
Emberson, L., Wieser, G., and Ashmore, M.: Modelling of stomatal conductance and ozone flux of Norway spruce: comparison with field data, Environ. Pollut., 109, 393-402, 2000b.

Emberson, L., Ashmore, M., Simpson, D., Tuovinen, J.-P., and Cambridge, H.: Modelling and mapping ozone deposition in Europe, Water Air Soil Pollut., 130, 577-582, 2001.

Emberson, L. D., Büker, P., and Ashmore, M. R.: Assessing the risk caused by ground level ozone to European forest trees: a case study in pine, beech and oak across different climate regions, Environ. Pollut., 147, 454-466, doi:10.1016/j.envpol.2006.10.026, 2007.

EMEP/CCC: Results from EMEP laboratory intercomparison, EMEP/CCC results on web, The Norwegian Institute for Air Research (NILU), Kjeller, Norway, http://www.nilu.no/projects/ ccc/intercomparison/index.html, 2014.

Engardt, M.: Sulphur simulations for East Asia using the MATCH model with meteorological data from ECMWF, RMK 88, Swedish Meteorological and Hydrological Institute, 33 pp., 2000.

Engardt, M. and Langner, J.: Simulations of future sulphur and nitrogen deposition over Europe using meteorological data from three regional climate projections, Tellus B, 65, 20348, doi:10.3402/tellusb.v65i0.20348, 2013.

Erisman, J. W., Hensen, A., Fowler, D., Flechard, C. R., Grüner, A., Spindler, G., Duyzer, J. H., Weststrate, H., Römer, F., Vonk, A. W., and Jaarsveld, H. V.: Dry deposition monitoring in Europe, Water Air Soil Pollut., 1, 17-27, 2001.

Erisman, J. W., Galloway, J. N., Seitzinger, S., Bleeker, A., Dise, N. B., Petrescu, A. M. R., Leach, A. M., and de Vries, W.: Consequences of human modification of the global nitrogen cycle, Philos.Trans. R. Soc. Lond. B. Biol. Sci., 368, doi:10.1098/rstb.2013.0116, 2013.

Fagerli, H. and Aas, W.: Trends of nitrogen in air and precipitation: model results and observations at EMEP sites in Europe, 19802003, Environ. Pollut., 154, 448-461, 2008.

Finlayson-Pitts, B. and Pitts, J.: Chemistry of the Upper and Lower Atmosphere - Theory, Experiments, and Applications, Academic Press, San Diego, CA, USA, 2000.

Flechard, C. R., Nemitz, E., Smith, R. I., Fowler, D., Vermeulen, A. T., Bleeker, A., Erisman, J. W., Simpson, D. Zhang, L., Tang, Y. S., and Sutton, M. A.: Dry deposition of reactive nitrogen to European ecosystems: a comparison of inferential models across the NitroEurope network, Atmos. Chem. Phys., 11, 2703-2728, doi:10.5194/acp-11-2703-2011, 2011.

Flechard, C. R., Massad, R.-S., Loubet, B., Personne, E., Simpson, D., Bash, J. O., Cooter, E. J., Nemitz, E., and Sutton, M. A.: Advances in understanding, models and parameterizations of biosphere-atmosphere ammonia exchange, Biogeosciences, 10, 5183-5225, doi:10.5194/bg-10-5183-2013, 2013.

Forkel, R. and Knoche, R.: Nested regional climate-chemistry simulations for central Europe, C. R. Geosci., 339, 734-746, doi:10.1016/j.crte.2007.09.018, 2007.

Fowler, D. and Erisman, J.: Biosphere/atmosphere exchange of pollutants, overview of subproject BIATEX-2, in: Towards Cleaner Air for Europe - Science, Tools and Applications, Part 2. Overviews from the Final Reports of the EUROTRAC-2 Subprojects, edited by: Midgley, P. and Reuther, M., Margraf Verlag, Weikersheim, also available at: http://www.gsf.de/eurotrac/ publications/ (last access: 22 February 2014), 2003. 
Fowler, D., Pilegaard, K., Sutton, M., Ambus, P., Raivonen, M., Duyzer, J., Simpson, D., Fagerli, H., Fuzzi, S., Schjoerring, J., Granier, C., Neftel, A., Isaksen, I., Laj, P., Maione, M., Monks, P., Burkhardt, J., Daemmgen, U., Neirynck, J., Personne, E., Wichink-Kruit, R., Butterbach-Bahl, K., Flechard, C., Tuovinen, J., Coyle, M., Gerosa, G., Loubet, B., Altimir, N., Gruenhage, L., Ammann, C., Cieslik, S., Paoletti, E., Mikkelsen, T., Ro-Poulsen, H., Cellier, P., Cape, J., Horváth, L., Loreto, F., Niinemets, Ü., Palmer, P., Rinne, J., Misztal, P., Nemitz, E., Nilsson, D., Pryor, S., Gallagher, M., Vesala, T., Skiba, U., Brüeggemann, N., Zechmeister-Boltenstern, S., Williams, J., O’Dowd, C., Facchini, M., de Leeuw, G., Flossman, A., Chaumerliac, N., and Erisman, J.: Atmospheric composition change: ecosystems-atmosphere interactions, Atmos. Environ., 43, 5193-5267, doi:10.1016/j.atmosenv.2009.07.068, 2009.

Frohn, L., Christensen, J., and Brandt, J.: Development and testing of numerical methods for two-way nested air pollution modelling, Phys. Chem. Earth, 27, 1487-1494, doi:10.1016/S14747065(02)00151-1, 2002.

Gallagher, M. W., Beswick, K. M., Duyzer, J., Westrate, H., Choularton, T. W., and Hummelshoj, P.: Measurements of aerosol fluxes to Speulder forest using a micrometeorological technique, Atmos. Environ., 31, 359-373, 1997.

Geels, C., Brandt, J., Christensen, J., Frohn, L., and Hansen, K.: Long-term calculations with a comprehensive nested hemispheric air pollution transport model, in: Advances in Air Pollution Modeling for Environmental Security, edited by: Faragó, I., Georgiev, K., and Havasi, Á., Springer, Netherlands, 185-196, 2005.

Geels, C., Andersen, H. V., Ambelas Skjøth, C., Christensen, J. H., Ellermann, T., Løfstrøm, P., Gyldenkærne, S., Brandt, J., Hansen, K. M., Frohn, L. M., and Hertel, O.: Improved modelling of atmospheric ammonia over Denmark using the coupled modelling system DAMOS, Biogeosciences, 9, 2625-2647, doi:10.5194/bg-9-2625-2012, 2012a.

Geels, C., Hansen, K. M., Christensen, J. H., Ambelas Skjøth, C., Ellermann, T., Hedegaard, G. B., Hertel, O., Frohn, L. M., Gross, A., and Brandt, J.: Projected change in atmospheric nitrogen deposition to the Baltic Sea towards 2020, Atmos. Chem. Phys., 12, 2615-2629, doi:10.5194/acp-12-2615-2012, 2012 b.

Guenther, A., Hewitt, C., Erickson, D., Fall, R., Geron, C., Graedel, T., Harley, P., Klinger, L., Lerdau, M., McKay, W., Pierce, T., Scholes, R., Steinbrecher, R., Tallamraju, R., Taylor, J., and Zimmerman, P.: A global model of natural volatile organic compound emissions, J. Geophys. Res., 100, 8873-8892, doi:10.1029/94JD02950, 1995.

Hansen, K., Pihl Karlsson, G., Ferm, M., Karlsson, P., Bennet, C., Granat, L., Kronnäs, V., von Brömssen, C., Engardt, M., Akselsson, C., Simpson, D., Hellsten, S., and Svensson, A.: Trender i kvävenedfall över Sverige 1955-2011, (In Swedish, abstract also in English), IVL Rapport B 2119, Swedish Environmental Research Institute (IVL), www.ivl.se/download/18. 372c2b801403903d2757ade/1383582083173/B2, 2013.

Hedegaard, G. B., Brandt, J., Christensen, J. H., Frohn, L. M., Geels, C., Hansen, K. M., and Stendel, M.: Impacts of climate change on air pollution levels in the Northern Hemisphere with special focus on Europe and the Arctic, Atmos. Chem. Phys., 8, 3337-3367, doi:10.5194/acp-8-3337-2008, 2008.
Hedegaard, G. B., Christensen, J. H., and Brandt, J.: The relative importance of impacts from climate change vs. emissions change on air pollution levels in the 21st century, Atmos. Chem. Phys., 13, 3569-3585, doi:10.5194/acp-13-3569-2013, 2013.

Hertel, O., Christensen, J., Runge, E., Asman, W., Berkowicz, R., Hovmand, M., and Hov, O.: Development and testing of a new variable scale air-pollution model - ACDEP, Atmos. Environ., 29, 1267-1290, 1995.

Hettelingh, J., Posch, M., DeSmet, P. A. M., and Downing, J. R.: The use of critical loads in emission reduction agreements in Europe, Water Air Soil Pollut., 85, 2381-2388, doi:10.1007/BF01186190, 1995.

Hettelingh, J.-P., Posch, M., and de Smet, P. A. M.: Multi-effect critical loads used in multi-pollutant reduction agreements in Europe, Water Air Soil Pollut., 130, 1133-1138, 2001.

Hijioka, Y., Matsuoka, Y., Nishimoto, H., Masui, M., and Kainuma, M.: Global GHG emissions scenarios under GHG concentration stabilization targets, Journal of Global Environmental Engineering, 13, 97-108, 2008.

Hole, L. and Engardt, M.: Climate change impact on atmospheric nitrogen deposition in northwestern Europe: a model study, Ambio, 37, 9-17, 2008.

Hole, L. R., Christensen, J. H., Ruoho-Airola, T., Torseth, K., Ginzburg, V., and Glowacki, P.: Past and future trends in concentrations of sulphur and nitrogen compounds in the Arctic, Atmos. Environ., 43, 928-939, doi:10.1016/j.atmosenv.2008.10.043, 2009.

Horn, H., Bonka, H., and Maqua, M.: Measured particle bound activity size-distribution, deposition velocity, and activity concentration in rainwater after the Chernobyl accident, J. Aerosol Sci., 18, 681-684, doi:10.1016/0021-8502(87)90096-6, 1987.

Huijnen, V., Eskes, H. J., Poupkou, A., Elbern, H., Boersma, K. F., Foret, G., Sofiev, M., Valdebenito, A., Flemming, J., Stein, O., Gross, A., Robertson, L., D’Isidoro, M., Kioutsioukis, I., Friese, E., Amstrup, B., Bergstrom, R., Strunk, A., Vira, J., Zyryanov, D., Maurizi, A., Melas, D., Peuch, V.-H., and Zerefos, C.: Comparison of $\mathrm{OMI} \mathrm{NO}_{2}$ tropospheric columns with an ensemble of global and European regional air quality models, Atmos. Chem. Phys., 10, 3273-3296, doi:10.5194/acp-10-32732010, 2010.

John, J. G., Fiore, A. M., Naik, V., Horowitz, L. W., and Dunne, J. P.: Climate versus emission drivers of methane lifetime against loss by tropospheric OH from 1860-2100, Atmos. Chem. Phys., 12, 12021-12036, doi:10.5194/acp-12-12021-2012, 2012.

Jonson, J., Simpson, D., Fagerli, H., and Solberg, S.: Can we explain the trends in European ozone levels?, Atmos. Chem. Physics, 6, 51-66, http://http://www.atmos-chem-phys.net/6/51/ 2006/, sRef-ID: 1680-7324/acp/2006-6-51, 2006.

Jylhä, K.: Empirical scavenging coefficients of radioactive substances released from Chernobyl, Atmos. Environ. A-Gen., 25, 263-270, doi:10.1016/0960-1686(91)90297-K, 1991.

Kjellstrom, E., Nikulin, G., Hansson, U., Strandberg, G., and Ullerstig, A.: 21st century changes in the European climate: uncertainties derived from an ensemble of regional climate model simulations, Tellus A, 63, 24-40, doi:10.1111/j.16000870.2010.00475.x, 2011.

Klingberg, J., Danielsson, H., Simpson, D., and Pleijel, H.: Comparison of modelled and measured ozone concentrations and me- 
teorology for a site in south-west Sweden: implications for ozone uptake calculations, Environ. Pollut., 115, 99-111, 2008.

Kouznetsov, R. and Sofiev, M.: A methodology for evaluation of vertical dispersion and dry deposition of atmospheric aerosols, J. Geophys. Res., 117, D01202doi:10.1029/2011JD016366, 2012.

Kuenen, J., Denier van der Gon, H., Visschedijk, A., van der Brugh, H., and van Gijlswijk, R.: MACC European emission inventory for the years 2003-2007, TNO Report TNO-060-UT2011-00588, TNO, Utrecht, the Netherlands, 2011.

Kukkonen, J., Olsson, T., Schultz, D. M., Baklanov, A., Klein, T., Miranda, A. I., Monteiro, A., Hirtl, M., Tarvainen, V., Boy, M., Peuch, V.-H., Poupkou, A., Kioutsioukis, I., Finardi, S., Sofiev, M., Sokhi, R., Lehtinen, K. E. J., Karatzas, K., San José, R., Astitha, M., Kallos, G., Schaap, M., Reimer, E., Jakobs, H., and Eben, K.: A review of operational, regional-scale, chemical weather forecasting models in Europe, Atmos. Chem. Phys., 12, 1-87, doi:10.5194/acp-12-1-2012, 2012.

Lamarque, J., Kiehl, J., Brasseur, G., Butler, T., Cameron-Smith, P., Collins, W., Collins, W., Granier, C., Hauglustaine, D., Hess, P., Holland, E., Horowitz, L., Lawrence, M., McKenna, D., Merilees, P., Prather, M., Rasch, P., Rotman, D., Shindell, D., and Thornton, P.: Assessing future nitrogen deposition and carbon cycle feedback using a multimodel approach: analysis of nitrogen deposition, J. Geophys. Res., 110, D19303, doi:10.1029/2005JD005825, 2005.

Lamaud, E., Brunet, Y., Labatut, A., Lopez, A., Fontan, J., and Druilhet, A.: The Landes experiment: biosphere-atmosphere exchanges of ozone and aerosol particles above a pine forest, J. Geophys. Res., 99, 16511-16521, doi:10.1029/94JD00668, 1994.

Langner, J., Bergström, R., and Pleijel, K.: European scale modeling of sulfur, oxidised nitrogen and photochemical oxidants, Model development and evaluation for the 1994 growing season, RMK No. 82, Swedish Meteorological and Hydrological Institute, (with errata), Norrköping, Sweden, 1998.

Langner, J., Bergstrom, R., and Foltescu, V.: Impact of climate change on surface ozone and deposition of sulphur and nitrogen in Europe, Atmos. Environ., 39, 1129-1141, doi:10.1016/j.atmosenv.2004.09.082, 2005.

Langner, J., Andersson, C., and Engardt, M.: Atmospheric input of nitrogen to the Baltic sea basin: present situation, variability due to meteorology and impact of climate change, Boreal Environ. Res., 14, 226-237, 2009.

Langner, J., Engardt, M., and Andersson, C.: European summer surface ozone 1990-2100, Atmos. Chem. Phys., 12, 10097-10105, doi:10.5194/acp-12-10097-2012, 2012a.

Langner, J., Engardt, M., Baklanov, A., Christensen, J. H., Gauss, M., Geels, C., Hedegaard, G. B., Nuterman, R., Simpson, D., Soares, J., Sofiev, M., Wind, P., and Zakey, A.: A multi-model study of impacts of climate change on surface ozone in Europe, Atmos. Chem. Phys., 12, 10423-10440, doi:10.5194/acp-12-10423-2012, 2012 b.

Loubet, B., Milford, C., Sutton, M. A., and Cellier, P.: Investigation of the interaction between sources and sinks of atmospheric ammonia in an upland landscape using a simplified dispersionexchange model, J. Geophys. Res., 106, 24183-24195, 2001.

Loubet, B., Asman, W. A., Theobald, M. R., Hertel, O., Tang, Y. S., Robin, P., Hassouna, M., Dämmgen, U., Genermont, S., Cellier, P., and Sutton, M. A.: Ammonia deposition near hot spots: processes, models and monitoring methods, in: Atmospheric Ammonia, Detecting Emissions Changes and Environmental Impacts, edited by: Sutton, M. A., Reis, S., and Baker, S. M., Springer, 205-267, Dordrecht, Netherlands, 2009.

Massad, R.-S., Nemitz, E., and Sutton, M. A.: Review and parameterisation of bi-directional ammonia exchange between vegetation and the atmosphere, Atmos. Chem. Phys., 10, 10359-10386, doi:10.5194/acp-10-10359-2010, 2010.

Nakićenović, N.: Global greenhouse gas emissions scenarios: integrated modeling approaches, Technol. Forecast. Soc., 63, 105109, 2000.

Nemitz, E. and Sutton, M. A.: Gas-particle interactions above a Dutch heathland: III. Modelling the influence of the $\mathrm{NH}_{3}-\mathrm{HNO}_{3}-$ $\mathrm{NH}_{4} \mathrm{NO}_{3}$ equilibrium on size-segregated particle fluxes, Atmos. Chem. Phys., 4, 1025-1045, doi:10.5194/acp-4-1025-2004, 2004.

Nemitz, E., Sutton, M. A., Wyers, G. P., Otjes, R. P., Mennen, M. G., van Putten, E. M., and Gallagher, M. W.: Gas-particle interactions above a Dutch heathland: II. Concentrations and surface exchange fluxes of atmospheric particles, Atmos. Chem. Phys., 4, 1007-1024, doi:10.5194/acp-4-1007-2004, 2004.

Nilsson, J. and Grennfelt, P. (eds.): Critical Loads for Sulphur and Nitrogen, Nord 1988:97, Nordic Council of Ministers, Copenhagen, Denmark, Nord 1988:97, 418 pp., 1988.

Posch, M., DeSmet, P. A. M., Hettelingh, J.-P., and Downing, J. R. (Eds.): Modelling and mapping of critical thresholds in Europe, Status report 2001, Coordination Centre for Effects, RIVM, Bilthoven, the Netherlands, 2001.

Posch, M., Slootweg, J., and Hettelingh, J. (eds.): Modelling critical thresholds and temporal changes of geochemistry and vegetation diversity, CCE Status Report 2011, 680359003, RIVM, Bilthoven, the Netherlands, available at: www.wge-cce.org (last access: 2 February 2014), 2011.

Posch, M., Slootweg, J., and Hettelingh, J. (eds.): Modelling and mapping of atmospherically-induced ecosystem impacts in Europe: CCE Status Report 2012, 680359004, RIVM, Bilthoven, the Netherlands, available at: www.wge-cce.org (last access: 2 February 2014), 2012.

Pryor, S. C., Gallagher, M., Sievering, H., Larsen, S. E., Barthelmie, R. J., Birsan, F., Nemitz, E., Rinne, J., Kulmala, M., Groenholm, T., Taipale, R., and Vesala, T.: A review of measurement and modelling results of particle atmospheresurface exchange, Tellus, 60, 42-75, doi:10.1111/j.16000889.2007.00298.x, 2008.

Reis, S., Grennfelt, P., Klimont, Z., Amann, M., ApSimon, H., Hettelingh, J.-P., Holland, M., LeGall, A.-C., Maas, R., Posch, M., Spranger, T., Sutton, M. A., and Williams, M.: From acid rain to climate change, Science, 338, 1153-1154, doi:10.1126/science.1226514, 2012.

Robertson, L., Langner, J., and Engardt, M.: An Eulerian limitedarea atmospheric transport model, J. Appl. Meteorol., 38, 190210, 1999.

Roeckner, E., Brokopf, R., Esch, M., Giorgetta, M., Hagemann, S., Kornblueh, L., Manzini, E., Schlese, U., and Schulzweida, U.: Sensitivity of simulated climate to horizontal and vertical resolution in the ECHAM5 atmosphere model, J. Climate, 19, 37713791, doi:10.1175/JCLI3824.1, 2006.

Samuelsson, P., Jones, C. G., Willen, U., Ullerstig, A., Gollvik, S., Hansson, U., Jansson, C., Kjellstrom, E., Nikulin, G., 
and Wyser, K.: The Rossby Centre Regional Climate model RCA3: model description and performance, Tellus A, 63, 4-23, doi:10.1111/j.1600-0870.2010.00478.x, 2011.

Sanderson, M., Dentener, F., Fiore, A., Cuvelier, K., Keating, T., Zuber, A., Atherton, C., Bergmann, D., Diehl, T., Doherty, R., Duncan, B., Hess, P., Horowitz, L., Jacob, D., Jonson, J., Kaminski, J., Lupu, A., Mackenzie, I., Mancini, E., Marmer, E., Park, R., Pitari, G., Prather, M., Pringle, K., Schroeder, S., Schultz, M., Shindell, D., Szopa, S., Wild, O., and Wind, P.: A multi-model study of the hemispheric transport and deposition of oxidised nitrogen, Geophys. Res. Lett., 35, L17815, doi:10.1029/2008GL035389, 2008.

Schulz, M., Benedictow, A., Schneider, P., Bartnicki, J., Valdebenito, Á., Gauss, M., and Griesfeller, J.: Modelling and evaluation of trends in the EMEP framework, in: Transboundary acidification, eutrophication and ground level ozone in Europe in 2011. EMEP Status Report 1/2013, pp. 85-104, The Norwegian Meteorological Institute, Oslo, Norway, 2013.

Simpson, D., Andersson-Sköld, Y., and Jenkin, M. E.: Updating the chemical scheme for the EMEP MSC-W oxidant model: current status, EMEP MSC-W Note 2/93, The Norwegian Meteorological Institute, Oslo, Norway, 1993.

Simpson, D., Winiwarter, W., Börjesson, G., Cinderby, S., Ferreiro, A., Guenther, A., Hewitt, C. N., Janson, R., Khalil, M. A. K., Owen, S., Pierce, T. E., Puxbaum, H., Shearer, M., Skiba, U., Steinbrecher, R., Tarrasón, L., and Öquist, M. G.: Inventorying emissions from nature in Europe, J. Geophys. Res., 104, 8113-8152, 1999.

Simpson, D., Tuovinen, J.-P., Emberson, L., and Ashmore, M.: Characteristics of an ozone deposition module, Water Air Soil Pollut., 1, 253-262, 2001.

Simpson, D., Fagerli, H., Jonson, J., Tsyro, S., Wind, P., and Tuovinen, J.-P.: The EMEP Unified Eulerian Model, Model Description, EMEP MSC-W Report 1/2003, The Norwegian Meteorological Institute, Oslo, Norway, 2003a.

Simpson, D., Tuovinen, J.-P., Emberson, L., and Ashmore, M.: Characteristics of an ozone deposition module II: sensitivity analysis, Water Air Soil Pollut., 143, 123-137, 2003 b.

Simpson, D., Butterbach-Bahl, K., Fagerli, H., Kesik, M., Skiba, U., and Tang, S.: Deposition and emissions of reactive nitrogen over European forests: a modelling study, Atmos. Environ., 40, 57125726, doi:10.1016/j.atmosenv.2006.04.063, 2006a.

Simpson, D., Fagerli, H., Hellsten, S., Knulst, J. C., and Westling, O.: Comparison of modelled and monitored deposition fluxes of sulphur and nitrogen to ICP-forest sites in Europe, Biogeosciences, 3, 337-355, doi:10.5194/bg-3-337-2006, 2006b.

Simpson, D., Benedictow, A., Berge, H., Bergström, R., Emberson, L. D., Fagerli, H., Flechard, C. R., Hayman, G. D., Gauss, M., Jonson, J. E., Jenkin, M. E., Nyíri, A., Richter, C., Semeena, V. S., Tsyro, S., Tuovinen, J.-P., Valdebenito, Á., and Wind, P.: The EMEP MSC-W chemical transport model - technical description, Atmos. Chem. Phys., 12, 7825-7865, doi:10.5194/acp-12-7825-2012, 2012.

Skjøth, C. A. and Geels, C.: The effect of climate and climate change on ammonia emissions in Europe, Atmos. Chem. Phys., 13, 117-128, doi:10.5194/acp-13-117-2013, 2013.

Skjøth, C. A., Geels, C., Berge, H., Gyldenkærne, S., Fagerli, H., Ellermann, T., Frohn, L. M., Christensen, J., Hansen, K. M., Hansen, K., and Hertel, O.: Spatial and temporal variations in ammonia emissions - a freely accessible model code for Europe, Atmos. Chem. Phys., 11, 5221-5236, doi:10.5194/acp-11-52212011, 2011.

Smith, F. B. and Clark, M. J.: The transport and deposition of radioactive debris from the Chernobyl nuclear power plant accident with special emphasis on consequences to the UK, Meteorological Office Scientific Paper N42, Meteorological Office Scientific Paper, HMSO, London, 1989.

Sofiev, M.: A model for the evaluation of long-term airborne pollution transport at regional and continental scales, Atmos. Environ., 34, 2481-2493, 2000.

Sofiev, M., Siljamo, P., Valkama, I., Ilvonen, M., and Kukkonen, J.: A dispersion modelling system SILAM and its evaluation against ETEX data, Atmos. Environ., 40, 674-685, doi:10.1016/j.atmosenv.2005.09.069, 2006.

Sofiev, M., Galperin, M., and Genikhovich, E.: A construction and evaluation of Eulerian dynamic core for the air quality and emergency modelling system SILAM, in: Air Pollution Modeling and its Application XIX, edited by: Borrego, C. and Miranda, A. I., Nato Science for Peace and Security Series C - Environmental Security, NATO; CCMS; Univ Aveiro, doi:10.1007/978-1-40208453-9_94, 699-701, 2008.

Sofiev, M., Genikhovich, E., Keronen, P., and Vesala, T.: Diagnosing the surface layer parameters for dispersion models within the meteorological-to-dispersion modeling interface, J. Appl. Meteorol. Clim., 49, 221-233, doi:10.1175/2009JAMC2210.1, 2010.

Solazzo, E., Bianconi, R., Vautard, R., Appel, K. W., Moran, M. D., Hogrefe, C., Bessagnet, B., Brandt, J., Christensen, J. H., Chemel, C., Coll, I., van der Gon, H. D., Ferreira, J., Forkel, R., Francis, X. V., Grell, G., Grossi, P., Hansen, A. B., Jericevic, A., Kraljevic, L., Miranda, A. I., Nopmongcol, U., Pirovano, G., Prank, M., Riccio, A., Sartelet, K. N., Schaap, M., Silver, J. D., Sokhi, R. S., Vira, J., Werhahn, J., Wolke, R., Yarwood, G., Zhang, J., Rao, S. T., and Galmarini, S.: Model evaluation and ensemble modelling of surface-level ozone in Europe and North America in the context of AQMEII, Atmos. Environ., 53, 60-74, doi:10.1016/j.atmosenv.2012.01.003, 2012.

Stohl, A., Klimont, Z., Eckhardt, S., Kupiainen, K., Shevchenko, V. P., Kopeikin, V. M., and Novigatsky, A. N.: Black carbon in the Arctic: the underestimated role of gas flaring and residential combustion emissions, Atmos. Chem. Phys., 13, 8833-8855, doi:10.5194/acp-13-8833-2013, 2013.

Strand, A. and Hov, O.: A 2-dimensional global study of tropospheric ozone production, J. Geophys. Res., 99, 22877-22895, doi:10.1029/94JD01945, 1994.

Sutton, M., Schjorring, J., and Wyers, G.: Plant atmosphere exchange of ammonia, Philos. T. Roy. Soc. Lond. A, 351, 261-276, 1995.

Sutton, M., Howard, C., Erisman, J., Billen, G., Bleeker, A., Grennfelt, P., van Grinsven, H., and Grizetti, B. (eds.): The European Nitrogen Assessment, Sources, Effects and Policy Perspectives, Cambridge University Press, New York, 2011.

Sutton, M. A., Reis, S., Riddick, S. N., Dragosits, U., Nemitz, E., Theobald, M. R., Tang, Y. S., Braban, C. F., Vieno, M., Dore, A. J., Mitchell, R. F., Wanless, S., Daunt, F., Fowler, D., Blackall, T. D., Milford, C., Flechard, C. R., Loubet, B., Massad, R., Cellier, P., Personne, E., Coheur, P. F., Clarisse, L., Van Damme, M., Ngadi, Y., Clerbaux, C., Skjøth, C. A., Geels, C., Hertel, O., Wichink Kruit, R. J., Pinder, R. W., 
Bash, J. O., Walker, J. T., Simpson, D., Horváth, L., Misselbrook, T. H., Bleeker, A., Dentener, F., and de Vries, W.: Towards a climate-dependent paradigm of ammonia emission and deposition, Philos. T. Roy. Soc. B, 368, 162120130166 , doi:10.1098/rstb.2013.0166, 2013.

Thunis, P., Rouil, L., Cuvelier, C., Stern, R., Kerschbaumer, A., Bessagnet, B., Schaap, M., Builtjes, P., Tarrason, L., Douros, J., Moussiopoulos, N., Pirovano, G., and Bedogni, M.: Analysis of model responses to emission-reduction scenarios within the CityDelta project, Atmos. Environ., 41, 208-220, 2007.

Tørseth, K., Aas, W., Breivik, K., Fjæraa, A. M., Fiebig, M., Hjellbrekke, A. G., Lund Myhre, C., Solberg, S., and Yttri, K. E.: Introduction to the European Monitoring and Evaluation Programme (EMEP) and observed atmospheric composition change during 1972-2009, Atmos. Chem. Phys., 12, 5447-5481, doi:10.5194/acp-12-5447-2012, 2012.

Tuovinen, J.-P., Simpson, D., Mikkelsen, T. N., Emberson, L. D., Ashmore, M. R., Aurela, M., Cambridge, H. M., Hovmand, M. F., Jensen, N. O., Laurila, T., Pilegaard, K., and Ro-Poulsen, $\mathrm{H}$.: Comparisons of measured and modelled ozone deposition to forests in Northern Europe, Water Air Soil Pollut., 1, 263-274, 2001

Tuovinen, J.-P., Ashmore, M., Emberson, L., and Simpson, D.: Testing and improving the EMEP ozone deposition module, Atmos. Environ., 38, 2373-2385, 2004.

Tuovinen, J.-P., Hakola, H., Karlsson, P. E., and Simpson, D.: Air pollution risks to Northern European forests in a changing climate, in: Climate Change, Air Pollution and Global Challenges Understanding and Perspectives from Forest Research, edited by: Matyssek, R., Clarke, N., Cudlin, P., Mikkelsen, T., Tuovinen, J., Wieser, G., and Paoletti, E., vol. 13 of Developments in Environmental Science, chap. 5, Elsevier, doi:10.1016/B978-008-098349-3.00005-0, Oxford, UK, 77-99, 2013.

UNECE: Manual on methodologies and criteria for modelling and mapping critical loads and levels, and air pollution effects, risks and trends, Tech. rep., UNECE Convention on Long-range Transboundary Air Pollution, available at: www.icpmapping.org (last access: 22 February 2014), 2004.

van der Linden, P. and Mitchell, J. F. B.: ENSEMBLES: Climate Change and its Impacts: Summary of research and results from the ENSEMBLES project, Tech. rep., Met Office Hadley Centre, FitzRoy Road, Exeter EX1 3PB, UK, available at: http://ensembles-eu.metoffice.com/docs/ Ensembles_final_report_Nov09.pdf, 2009. van Loon, M., Vautard, R., Schaap, M., Bergstrom, R., Bessagnet, B., Brandt, J., Builtjes, P., Christensen, J., Cuvelier, C., Graff, A., Jonson, J., Krol, M., Langner, J., Roberts, P., Rouil, L., Stern, R., Tarrason, L., Thunis, P., Vignati, E., White, L., and Wind, P.: Evaluation of long-term ozone simulations from seven regional air quality models and their ensemble, Atmos. Environ., 41, 2083-2097, 2007.

van Vuuren, D., Edmonds, J., Kainuma, M., Riahi, K., and Weyant, J.: A special issue on the RCPs, Climatic Change, 109, 1-4, http://dx.doi.org/10.1007/s10584-011-0157-y, 10.1007/s10584011-0157-y, 2011

Vautard, R., Van Loon, M., Schaap, M., Bergstroem, R., Bessagnet, B., Brandt, J., Builtjes, P. J. H., Christensen, J. H., Cuvelier, C., Graff, A., Jonson, J. E., Krol, M., Langner, J., Roberts, P., Rouil, L., Stern, R., Tarrason, L., Thunis, P., Vignati, E., White, L., and Wind, P.: Is regional air quality model diversity representative of uncertainty for ozone simulation?, Geophys. Res. Lett., 33, L24818, doi:10.1029/2006GL027610, 2006.

Vautard, R., Builtjes, P., Thunis, P., Cuvelier, C., Bedogni, M., Bessagnet, B., Honore, C., Moussiopoulos, N., Pirovano, G., Schaap, M., Stern, R., Tarrason, L., and Wind, P.: Evaluation and intercomparison of ozone and $\mathrm{PM}_{10}$ simulations by several chemistry transport models over four European cities within the CityDelta project, Atmos. Environ., 41, 173-188, doi:10.1016/j.atmosenv.2006.07.039, 2007.

Wesely, M. L., Cook, D. R., Hart, R. L., and Speer, R. E.: Measurements and parameterization of particulate sulfur dry deposition over grass, J. Geophys. Res., 90, 2131-2143, 1985.

Wichink-Kruit, R., van Pul, W., Sauter, F., van den Broek, M., Nemitz, E., Sutton, M., Krol, M., and Holtslag, A.: Modeling the surface-atmosphere exchange of ammonia, Atmos. Environ., 44, 945-957, doi:10.1016/j.atmosenv.2009.11.049, 2010.

Wichink-Kruit, R. J., Schaap, M., Sauter, F. J., van Zanten, M. C., and van Pul, W. A. J.: Modeling the distribution of ammonia across Europe including bi-directional surface-atmosphere exchange, Biogeosciences, 9, 5261-5277, doi:10.5194/bg-9-52612012, 2012.

Winiwarter, W. and Hettelingh, J.-P. (with 14 contributing authors): Future scenarios of nitrogen in Europe, in: The European Nitrogen Assessment. Sources, Effects and Policy Perspectives, edited by Sutton, M., Howard, C., Erisman, J., Billen, G., Bleeker, A., Grennfelt, P., van Grinsven, H., and Grizetti, B., chap. 24, pp. 551-569, Cambridge University Press, http://www.nine-esf.org/ ENA-Book, 2011. 